\title{
GENETIC MURINE MODELS OF SPINAL DEVELOPMENT AND DEGENERATION PROVIDE VALUABLE INSIGHTS INTO INTERVERTEBRAL DISC PATHOBIOLOGY
}

\author{
J. Melrose ${ }^{1,2,3,, *}$, S. Tessier ${ }^{4,5, \$}$ and M.V. Risbud ${ }^{5,6, *}$ \\ ${ }^{1}$ Research Associate, Kolling Institute of Medical Research and the Institute of Bone and Joint Research, \\ North Sydney Area Health Authority, University of Sydney at the Royal North Shore Hospital, \\ St. Leonards, New South Wales 2065, Australia \\ ${ }^{2}$ Department of Surgery, Northern Clinical School, University of Sydney, Australia \\ ${ }^{3}$ Professor Graduate School of Biomedical Engineering, The University of New South Wales, Australia \\ ${ }^{4}$ Lewis Katz School of Medicine, Temple University, Philadelphia, PA, USA \\ ${ }^{5}$ Department of Orthopaedic Surgery, Sidney Kimmel Medical College, Thomas Jefferson University, \\ Philadelphia, PA, USA \\ ${ }^{6}$ Graduate Program in Cell Biology and Regenerative Medicine, Jefferson College of Life Sciences, \\ Thomas Jefferson University, Philadelphia, PA, USA \\ $\S$ These authors contributed equally to this work
}

\begin{abstract}
Disc degeneration and associated back and neck pain elicits a substantial burden on healthcare systems and the individuals affected, necessitating the development of novel therapeutic strategies. This goal can only be achieved by a better understanding of intervertebral disc development, homeostasis and pathogenesis. A number of genetic and in-bred murine models are reviewed to underscore the importance of the mouse as an animal model of choice for the assessment of intervertebral disc pathobiology. Appraisals of the differences between mouse and human musculoskeletal systems and proteoglycan structures are also included. A number of important target pathways and molecules have been identified, many of which are worthy of further examination, requiring that the activity of these be confirmed in large animal models and assessed in the context of therapeutic intervention.
\end{abstract}

Keywords: Murine model, intervertebral disc, nucleus pulposus, annulus fibrosus, spine.

*Address for correspondence: Makarand V. Risbud, PhD, Department of Orthopaedic Surgery, Thomas Jefferson University, 1025 Walnut Street, Suite 501 College Bldg., Philadelphia, PA 19107, USA.

Fax number: +1 2159559159 Email: makarand.risbud@jefferson.edu

Copyright policy: This article is distributed in accordance with Creative Commons Attribution Licence (http://creativecommons.org/licenses/by-sa/4.0/).

\begin{tabular}{|c|c|c|c|}
\hline \multirow{5}{*}{ ADAMTS } & \multirow[t]{2}{*}{ List of Abbreviations } & \multirow{2}{*}{$\begin{array}{l}\text { BACH-1 } \\
\text { BGN }\end{array}$} & \multirow{2}{*}{$\begin{array}{l}\text { BTB and CNC homology-1 } \\
\text { biglycan }\end{array}$} \\
\hline & & & \\
\hline & a disintegrin and & BMP & bone morphogenic protein \\
\hline & metalloproteinase with & BNIP3 & BLC2 interacting protein 3 \\
\hline & thrombospondin motifs & CA3 & carbonic anhydrase 3 \\
\hline $\mathrm{AF}$ & annulus fibrosus & Can & aggrecan \\
\hline Akr1b1 & $\begin{array}{l}\text { aldo-keto reductase family } 1 \\
\text { member B }\end{array}$ & $\mathrm{Ccl} 2$ & $\begin{array}{l}\text { monocyte chemoattractant } \\
\text { protein-1, aka MCP-1 }\end{array}$ \\
\hline ALPL & alkaline phosphatase & CD44 & cluster of differentiation 44 \\
\hline ANK & ankyrin & CDK2 & cyclin-dependent kinase 2 \\
\hline AP-1 & activator protein 1 & CEP & cartilaginous endplates \\
\hline Aqp2 & aquaporin-2 & Chm1 & chondromodulin I \\
\hline ARP2/3 & actin-related proteins $2 / 3$ & COL1A1 & collagen type I alpha chain \\
\hline ATM & ataxia-telangiectasia mutated & COL2A1 & collagen type II alpha chain \\
\hline & kinase & COX-2 & cyclooxygenase-2 \\
\hline B3gat3 & beta-1,3-glucuronyltransferase 3 & CS & chondroitin sulphate \\
\hline
\end{tabular}




\begin{tabular}{|c|c|}
\hline CTGF & connective tissue growth factor \\
\hline E2F & elongation factor 2 \\
\hline ENPP1 & $\begin{array}{l}\text { ectonucleotide pyrophosphatase/ } \\
\text { phosphodiesterase } 1\end{array}$ \\
\hline ENT1 & $\begin{array}{l}\text { equilibrative nucleoside } \\
\text { transporter } 1\end{array}$ \\
\hline ERCC1 & $\begin{array}{l}\text { excision repair } 1 \text { endonuclease } \\
\text { non-catalytic subunit }\end{array}$ \\
\hline ERK & $\begin{array}{l}\text { extracellular signal-regulated } \\
\text { kinase }\end{array}$ \\
\hline FasL & Fas ligand \\
\hline FGF & fibroblast growth factor \\
\hline FGFRs & fibroblast growth factor receptors \\
\hline FLNB & filamin B \\
\hline FMOD & fibromodulin \\
\hline FOXA1/2 & forkhead box A1/A2 \\
\hline $\mathrm{FOXO} 1 / 3 / 4$ & forkhead box $\mathrm{O} 1 / \mathrm{O} 3 / \mathrm{O} 4$ \\
\hline GAG & glycosaminoglycan \\
\hline Gal & D-galactose \\
\hline GalNAc & N-acetylgalactosamine \\
\hline GDF5 & growth differentiation factor 5 \\
\hline GlcA & glucuronic acid \\
\hline GlcNAc & $\beta 1-3$ D-N-acetylglucosamine \\
\hline GlcUA & glucuronic acid \\
\hline HA & hyaluronic acid \\
\hline HAS2 & hyaluronan synthase 2 \\
\hline $\mathrm{HIF}-1 / 2 \alpha$ & $\begin{array}{l}\text { hypoxia-inducible factor } \\
\text { 1alpha/2alpha }\end{array}$ \\
\hline $\mathrm{HO}-1$ & haem oxygenase-1 \\
\hline HOX & homeobox \\
\hline HS & heparan sulphate \\
\hline Hspg2 & perlecan \\
\hline IGD & interglobular domain \\
\hline IGF-1 & insulin-like growth factor 1 \\
\hline IGFR & insulin-like growth factor receptor \\
\hline IL-1rn & interleukin 1 receptor antagonist \\
\hline IL- $1 \alpha / \beta$ & interleukin 1 alpha/beta \\
\hline IL-6 & interleukin-6 \\
\hline IVD & intervertebral disc \\
\hline JNK1/2 & Jun N-terminal kinase $1 / 2$ \\
\hline KS & keratan sulphate \\
\hline LAMSHF & Lamb-Shaffer syndrome \\
\hline LDL & low density lipoprotein \\
\hline LDLR & low density lipoprotein receptor \\
\hline LP & link protein \\
\hline LRP6 & $\begin{array}{l}\text { low-density lipoprotein receptor- } \\
\text { related protein } 6\end{array}$ \\
\hline MAPK & mitogen-activated protein kinase \\
\hline MCP-1 & $\begin{array}{l}\text { monocyte chemoattractant } \\
\text { protein-1 }\end{array}$ \\
\hline MCT4 & monocarboxylate transporter 4 \\
\hline $\mathrm{MKX}$ & Mohawk \\
\hline MMP & matrix metalloproteinase \\
\hline MT1-MMP & $\begin{array}{l}\text { membrane type 1-matrix } \\
\text { metalloproteinase, aka MMP14 }\end{array}$ \\
\hline mTOR & mechanistic target of rapamycin \\
\hline NF-1 & neurofibromatosis type 1 \\
\hline NFAT5 & nuclear factor of activated T-cells 5 \\
\hline NF- $\kappa \mathrm{B}$ & $\begin{array}{l}\text { nuclear factor kappa-light-chain- } \\
\text { enhancer of activated B cells }\end{array}$ \\
\hline NOTO & homeobox protein notochord \\
\hline
\end{tabular}

\begin{tabular}{|c|c|}
\hline NP & nucleus pulposus \\
\hline OREBP & $\begin{array}{l}\text { osmotic response element binding } \\
\text { protein }\end{array}$ \\
\hline p16 & $\begin{array}{l}\text { cyclin-dependent kinase inhibitor } \\
\text { 2A }\end{array}$ \\
\hline PAX1/9 & paired box $1 / 9$ \\
\hline PHLPP1 & $\begin{array}{l}\text { PH domain leucine-rich repeat } \\
\text { protein phosphatase }\end{array}$ \\
\hline PRG4 & lubricin \\
\hline $\mathrm{Pt}$ & Pintail \\
\hline PTCH1 & Patched 1 \\
\hline QTL & quantitative trait locus \\
\hline RAS & rat sarcoma \\
\hline RB1 & $\begin{array}{l}\text { retinoblastoma transcriptional } \\
\text { corepressor } 1\end{array}$ \\
\hline RHAMM & receptor for HA-mediated motility \\
\hline SCX & scleraxis \\
\hline Sd & Danforths short tail \\
\hline $\mathrm{SHH}$ & Sonic Hedgehog \\
\hline Skt & Sickle tail \\
\hline Slc6A6 & $\begin{array}{l}\text { sodium- and chloride-dependent } \\
\text { taurine transporter }\end{array}$ \\
\hline SLRP & small leucine-rich proteoglycan \\
\hline SMAD3 & $\begin{array}{l}\text { mothers against decapentaplegic } \\
\text { homologue } 3\end{array}$ \\
\hline Smo & smoothened \\
\hline SOX5/6/9 & Sry-related HMG box 5/6/9 \\
\hline SPARC & $\begin{array}{l}\text { secreted protein acidic and rich in } \\
\text { cysteine }\end{array}$ \\
\hline $\mathrm{T}$ & brachyury \\
\hline Tc & truncate \\
\hline Tgfb2 & TGF- $\beta$ type II receptor \\
\hline TGF- $\beta$ & transforming growth factor beta \\
\hline TNF- $\alpha$ & tumour necrosis factor alpha \\
\hline TNMD & tenomodulin \\
\hline TonEBP & tonicity enhancer binding protein \\
\hline TSC & tuberous sclerosis complex \\
\hline VEGF & vascular endothelial growth factor \\
\hline WNT & wingless/integrated \\
\hline
\end{tabular}

\section{Introduction}

\section{Insight into disc pathobiology through the murine model}

The murine model is an invaluable experimental tool for the investigation of several degenerative human conditions. Studies of a number of genetically modified mice have contributed immensely to our understanding of spinal development and homeostasis (Table 1-4). Indeed, manipulations of the mouse genome through mis-expression, knockingout, knocking-in, or the introduction of mutations into genes, as well as inbred mouse models, have transformed our understanding of spinal development and the complex functional properties of the IVD. In many cases, such mutants are also genetic models of relevant human degenerative disorders characterised by, for example, reduced bone mass (osteopenia, osteoporosis) or abnormalities in endochondral bone formation affecting development 
and growth of the skeleton (chondrodysplasias). The value of the murine model is further underscored by the high conservation of skeletal development between mice and humans, despite differences in skeletal size and time required for reaching skeletal maturity. From a regenerative perspective, understanding the regulatory molecules that are operative during such developmental processes provides information applicable to therapeutic tissue repair strategies (Tessier and Risbud, 2020). Moreover, the development of quantitative histopathological scoring schemes for murine IVDs have further increased the utility of the murine model for pathobiological evaluations. It is within this context that we have summarised numerous studies, whose insightful conclusions relied heavily upon the use of the mouse as an experimental model.

\section{Intervertebral disc structure and comparative anatomy}

The spinal column was evolutionarily preceded by the notochord, a rod-like structure that provided protection to the underlying neural tube and mechanical support to the chordate organism. In higher vertebrates, which possess the advantage of distinct spinal joints (syndesmosis/symphysis) consisting of mineralised vertebral bodies joined by IVDs, the notochord exits as merely a transient embryonic structure. While transient, it is crucial for mechanical support and morphogenic signalling during development. Its fate is to give rise to the NP, a tissue found at the centre of the IVD, distinguished for its gel-like appearance on gross examination, high proteoglycan content, and load-bearing properties. The uniqueness of the NP is further exemplified by its microenvironmental conditions (i.e. hyperosmolarity, hypoxia and loading), which have guided the focus of research efforts in the quest of delineating the molecular mechanisms that underly NP cell survival. Such salient discoveries, facilitated by the mouse model, will be discussed in this review. The circumferential disc tissue that surrounds the NP is called the AF. Under the microscope, the collagenous lamellae so characteristic of the AF are conspicuously prominent and show a graded transition between the inner-most and outer-most regions. AF cells, or annulocytes, also differ morphologically by regional location along the AF (Bruehlmann et al., 2002). Together, the NP and AF make up the bulk of disc tissue. Also important to disc anatomy are the thin layers of hyaline cartilage that form the superior and inferior boundaries, called the CEPs. It is their presence that prevents the disc from applying its biomechanical forces directly against the vertebral bone. The CEPs, due to their porous nature, permit diffusion and exchange of nutrients and metabolites between the vascular beds in subchondral vertebral bone and avascular compartments of the disc. This is a process facilitated by the diurnal loading and unloading of the spinal motion segments. The disc, along with the adjoining vertebrae, forms a complex polyaxial, diarthrodial joint that allows for wide ranges of 3-dimensional movement (Shapiro et al., 2012).

The murine IVD shares the structural characteristics described above with that of humans. An important difference to highlight, nonetheless, is that notochordlike NP cells persist longer in the murine model than in humans. The murine and human IVD are embryonically derived from the aggregation of the notochord and perinotochordal mesenchyme during vertebral column development. Notochordal cells produce a matrix rich in proteoglycan, important for generating central swelling pressure in the developing IVD and essential for normal NP formation (Adams et al., 1977). In humans, within 4 to 10 years of age after birth, the notochordal cells of the disc disappear or undergo significant morphological changes, whereas they persist throughout adulthood in the healthy murine system (Trout et al., 1982). Human NP cells acquire a round, chondrocytic appearance as they age, becoming increasingly dispersed throughout the matrix. By contrast, the adult vacuolated NP cells of the healthy mouse disc assemble into a central band. For reference to the histomorphology of human disc tissue, please consult the studies cited here (Boos et al., 2002; Rutges et al., 2013). Notochordal NP cells are large and vacuolated, often forming groups and clusters and described as a physaliforous cell type (Pandiar and Thammaiah, 2018). They are relatively quiescent with regards to proteoglycan metabolism, but have a marked influence on the metabolism of proteoglycans within the NP (Aguiar et al., 1999). A series of mouse mutants with defective notochordal development such as the Brachyury curtailed (Stott et al., 1993), Truncate (tc) (Theiler, 1959), Pintail (Pt) (Hollander and Strong, 1951), and Sickle tail (Skt) (Semba et al., 2006) allow for testing of the relationship between disc health and notochordal cell defects. These mutants show acceleration in age onset-IVD degeneration correlated with the loss of notochordal cells from the NP. In severe cases, the NP actually does not develop (Table 1). Accordingly, vacuolated notochord-like NP cells are typically associated with a healthy IVD.

There are other differences between humans and the murine system that should be taken into account. Unlike humans, for one, the quadrupedal mouse does not ambulate vertically. Quadrupedalism subjects the horizontally oriented spine to greater amounts of axial compression stress, which results in higher trabecular bone density when compared to humans. Nevertheless, both murine and human spines are primarily loaded along the cephalic-caudal axis, and the lumbar discs of both species are loaded by ground-reactionary and endogenous forces (Smit, 2002). The lumbar vertebrae and discs, too, are the largest in both species. When geometry is normalised, the average compressive and torsional stiffness of the murine disc is quite similar to that measured in humans (Elliott and Sarver, 2004). Another obvious difference is that the mouse has an additional 
vertebra at the thoracic and lumbar spinal levels, one vertebra less at the sacral level, and up to 28 coccygeal/tail vertebrae. The tail vertebrae and discs have morphological features that differ from the lumbar segments likely due to differences in weightbearing loads (Elliott and Sarver, 2004). In addition, there are important species-dependent differences in the structure of disc proteoglycans, which will be addressed in the following section.

\section{Consideration of differences between murine and human proteoglycans}

High proteoglycan content, most notably aggrecan, is a hallmark feature of the healthy IVD, as it provides the tissue with robust load-bearing properties. Structurally, the aggrecan core protein comprises 3 globular domains: G1 and G2, positioned at the $\mathrm{N}$-terminal end, and G3, positioned at the C-terminal end. The G1 and G2 domains are separated by an

Table 1. Mouse spinal models assessing the effects of mutations in genes to morphogens, regulatory signalling molecules, and transcription factors.

\begin{tabular}{|c|c|c|}
\hline Model & Phenotype/insight & References \\
\hline $\begin{array}{l}\text { Pintail }(P t) \text { and truncate } \\
\quad(t c) \text { mouse models }\end{array}$ & $\begin{array}{c}\text { Premature truncation of notochord /development of the vertebral column, loss of notochordal cells. Accelerated age } \\
\text { onset disc degeneration. Total absence of NP at all levels in the } S d \text { knockout mouse. }\end{array}$ & $\begin{array}{l}\text { Hollander and Strong, } \\
1951 \\
\text { Theiler, } 1959\end{array}$ \\
\hline Skt Sickle tail mouse & $\begin{array}{l}S k t \text { is a gene linked to the Danforth } S d \text { short tail locus, required for correct IVD development. Size of NP in WT mouse } \\
\text { is normal until birth, after birth the } S k t \text { NP does not expand and is dislocated to the periphery, resulting in a kinky tail } \\
\text { phenotype in the adult. }\end{array}$ & Semba et al., 2006 \\
\hline FOXA2 knockout & Defective node and notochord formation; secondary impairment of dorsal-ventral neural tube patterning. & Ang and Rossant, 1994 \\
\hline $\begin{array}{l}\text { Foxa1 }^{-/} ; \text {Foxa }^{c / c} ; \text { ShhcreER } \\
\text { double mutant }\end{array}$ & $\begin{array}{c}\begin{array}{c}\text { Defective notochord sheath, deformed NP, cell death, and reduced SHH signalling; secondary impairment of dorsal- } \\
\text { ventral neural tube patterning. }\end{array}\end{array}$ & Maier et al., 2013 \\
\hline T deficiency & $\begin{array}{c}\text { Homozygous null: lack notochord, abnormal somites, allantois defect, lethal. Haploinsufficiency: short-tailed } \\
\text { phenotype. }\end{array}$ & Stott et al., 1993 \\
\hline NOTO deficiency & Disruption of the caudal notochord. The autosomal recessive mutation in the mouse is known as Truncate (tc). & $\begin{array}{l}\text { Ben Abdelkhalek et } \\
\text { al., } 2004\end{array}$ \\
\hline TonEBP deficiency & $\begin{array}{l}\text { Homozygous null: delayed spinal development and expression of notochord markers. Haploinsufficiency: Accelerated } \\
\text { age-dependent degeneration, matrix fibrosis, alterations to the actin cytoskeleton, and decreased expression of } \\
\text { proinflammatory genes. }\end{array}$ & $\begin{array}{l}\text { Tessier et al., 2019, } \\
\quad 2019 \mathrm{~b}\end{array}$ \\
\hline MitoQC reporter & $\begin{array}{c}\text { NP cells possess numerous tubular and hypoxia-responsive mitochondrial networks that undergo increased } \\
\text { mitophagy with ageing. }\end{array}$ & Madhu et al., 2020 \\
\hline MCT4 knockout & Disc degeneration with increased aggrecan degradation, MMP13, and type $\mathrm{X}$ collagen levels. & Silagi et al., 2020 \\
\hline $\begin{array}{l}\text { Foxa2cre; } H \text { iff- } 1 \alpha^{\mathrm{n} / / \mathrm{l}} \\
\text { Shhcre; } H i f-1 \alpha^{\mathrm{n} / \mathrm{l}}\end{array}$ & Notochordal cell loss and severely prominent fibrosis of the disc by 1 month of age. & $\begin{array}{l}\text { Wu et al., } 2013 \\
\text { Merceron } \text { et al., } 2014\end{array}$ \\
\hline $\begin{array}{c}\text { Tnmd } \\
\text { Tnmd }^{-/} ; \text {Chm }^{-/}\end{array}$ & $\begin{array}{l}\text { Increased angiogenesis and macrophage invasion of the outer AF; accelerated disc degeneration including } \\
\text { hypertrophic cells residing in the NP compartment. }\end{array}$ & Lin et al., 2020 \\
\hline SOX5/6 double knockout & Defective notochord sheath formation, apoptosis of notochord cells, and spine lacking NP. & $\begin{array}{l}\text { Smits and Lefebvre, } \\
2003\end{array}$ \\
\hline SOX9 knockout & Notochord disintegration and disc degeneration. & Barrionuevo et al., 2006 \\
\hline AcanCre ${ }^{\text {ERT2 }}$ So $x 9^{\mathrm{f} / \mathrm{fl}}$ & $\begin{array}{c}\text { Severe degeneration of all disc compartments. Matrix remodelling, cell death, and compartment-specific } \\
\text { transcriptomic changes. }\end{array}$ & $\begin{array}{l}\text { Henry et al., } 2012 \\
\text { Tsingas et al., } 2020\end{array}$ \\
\hline PAX-1/9 double knockout & Vertebral column and disc defects; sclerotomes fail to undergo chondrogenesis. & Peters et al., 1999 \\
\hline MKX knockout & AF degeneration. & Nakamichi et al., 2016 \\
\hline BACH-1 knockout & Protective effects on annular puncture. & Ohta et al., 2012 \\
\hline 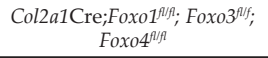 & Progressive increase in NP cellularity. Marked degeneration by 6 months. Kyphosis. & $\begin{array}{l}\text { Alvarez-Garcia et al., } \\
2018\end{array}$ \\
\hline 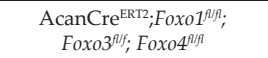 & Marked disc degeneration by 12 months of age. & $\begin{array}{l}\text { Alvarez-Garcia et al., } \\
2018\end{array}$ \\
\hline $\begin{array}{l}\text { Hoxd-3 knockout \& Hoxb- } \\
4 \text { knockout }\end{array}$ & $\begin{array}{c}\text { Transformation of atlas and axis of the craniocervical joint, deletion of dens and superior facet joints, axis shows atlas } \\
\text { like characteristics. }\end{array}$ & $\begin{array}{c}\text { Condie and Capecchi, } \\
1993) \\
\text { Ramfrez-Solis et al., } \\
1993\end{array}$ \\
\hline $\begin{array}{l}\text { Hox-10 knockout \& Hox-11 } \\
\text { knockout }\end{array}$ & $\begin{array}{l}\text { Lumbar vertebrae do not develop in Hox-10 knockouts, sacral vertebrae do not develop in Hox-11 knockouts; } \\
\text { associated downline abnormalities in IVD development. }\end{array}$ & $\begin{array}{l}\text { Wellik and Capecchi, } \\
2003\end{array}$ \\
\hline ShhGFPcre;Smo $o^{\mathrm{f} / \mathrm{fl}}$ & Defective notochord sheath formation, axial patterning, and IVDs. & Choi and Harfe, 2011 \\
\hline $\begin{array}{l}\text { Wnt// } \beta \text {-catenin knockout } \\
\text { reporter (TOPGAL) }\end{array}$ & $\begin{array}{c}\text { Deterioration of the GP and AF when } \beta \text {-catenin is overexpressed in both Col1a1 and Col2a1-expressing cells; accelerated } \\
\text { subchondral bone formation when } \beta \text {-catenin is deleted in Col2a1-expressing cells. }\end{array}$ & $\begin{array}{l}\text { Dahia et al., } 2009 \\
\text { Kondo et al., } 2011\end{array}$ \\
\hline NotoCre;Ccn $2^{\mathrm{f} / \mathrm{ll}}$ & $\begin{array}{c}\text { Age-associated degeneration of IVDs, decreased levels of aggrecan and type II collagen, and increased levels of type I } \\
\text { collagen within the NP. }\end{array}$ & Bedore et al., 2013 \\
\hline Col2aCre; Tgfbr $2^{\mathrm{n} / \mathrm{l}}$ & $\begin{array}{l}\text { Mutant embryos with irregularities in the size and shape of vertebrae. The intervertebral discs were either completely } \\
\text { lost or reduced in size due to AF defects. }\end{array}$ & Baffi et al., 2004, 2006 \\
\hline Acan $\mathrm{Cre}^{\mathrm{ERT2}} ; \mathrm{Tgfbr} 2^{\mathrm{Al} / \mathrm{l}}$ & Progressive degenerative phenotype with calcifications in the disc space by 12 months of age. & Alkhatib et al., 2018 \\
\hline SMAD-3 knockout & Spinal malformations and kyphosis, changes in CEP structure, and decreased IVD proteoglycan and collagen content. & Li et al., 2009 \\
\hline IGF1R haploinsufficiency & Accelerated disc degeneration. & Li et al., 2013 \\
\hline GDF-5 knockout & Reduced proteoglycan content. & Li et al., 2004 \\
\hline Col2a1Cre; $N f 1^{\mathrm{f} / \mathrm{l}}$ & Progressive scoliosis and kyphosis with IVD defects. & Wang et al., 2011 \\
\hline TSC1 knockout & Congenital spinal defects. & Yang et al., 2017 \\
\hline Col2a1Cre; Jnk1 $1^{1 / 1 / 1} / J n k 2^{-/}$ & Severe, early onset scoliosis with disc fusions. & Ulici et al., 2019 \\
\hline PHLPP1 knockout & Preserves cellularity and matrix homeostasis in an injury model. & Zhang et al., 2019 \\
\hline Ercc1 deficiency & $\begin{array}{l}\text { Advanced age-related degenerative changes in the vertebral bodies and intervertebral discs, including reduced } \\
\text { proteoglycan content, increased apoptosis, and increased p16. }\end{array}$ & Vo et al., 2010 \\
\hline $\begin{array}{l}\text { TNF } \alpha \text { overexpression } \\
(\mathrm{Tg} 197 \text { and } \mathrm{hTNF} \alpha \mathrm{Tg})\end{array}$ & $\begin{array}{c}\text { Compromised vertebral bone parameters, greater propensity for herniations at the EP/AF junction, evidence of AF } \\
\text { defects, expanded NP cell band. }\end{array}$ & Gorth et al., 2018, 2020 \\
\hline IL-1 $\alpha / \beta$ double knockout & Evidence of AF degeneration. & Gorth et al., 2019 \\
\hline AcanCreER ${ }^{\mathrm{T2}} ; p 16^{\text {Ink4a }}$ & Decreased senescence markers with age-dependent degenerative changes. & Novais et al., 2019 \\
\hline IL-1RN knockout & Spinal abnormalities. & Phillips et al., 2013 \\
\hline
\end{tabular}




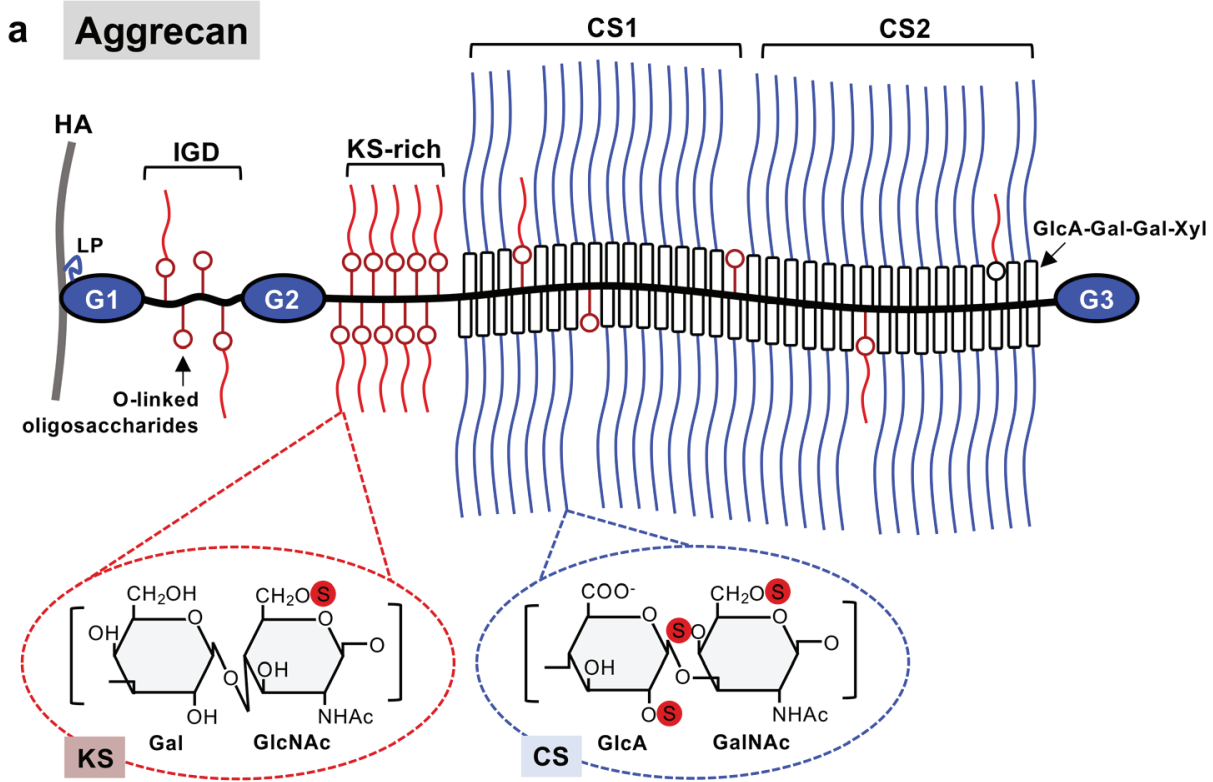

\section{b Perlecan}

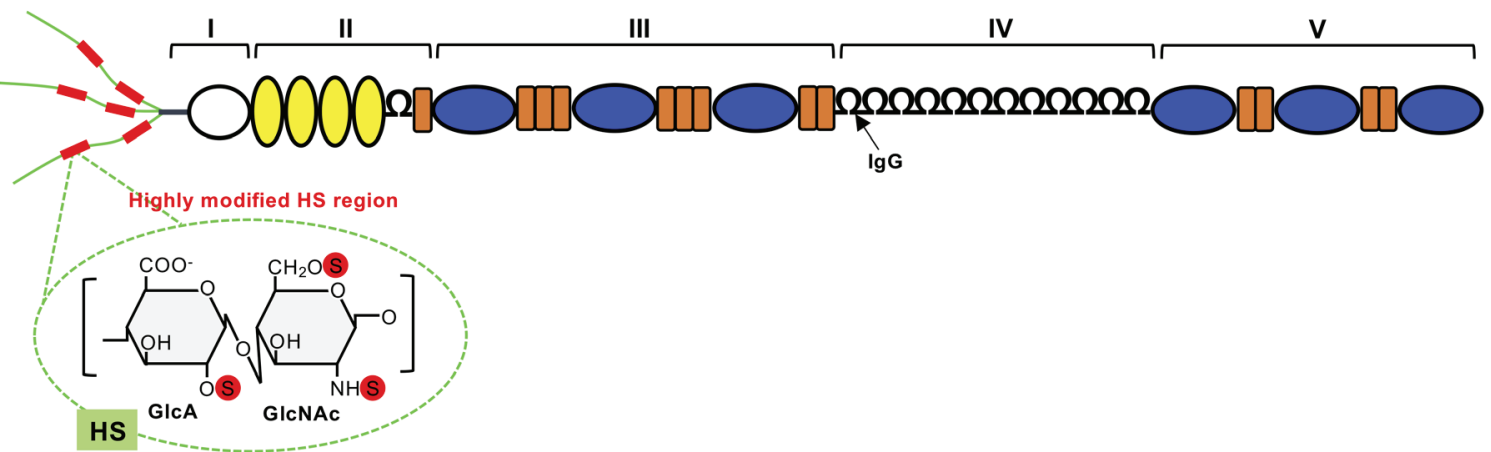

C
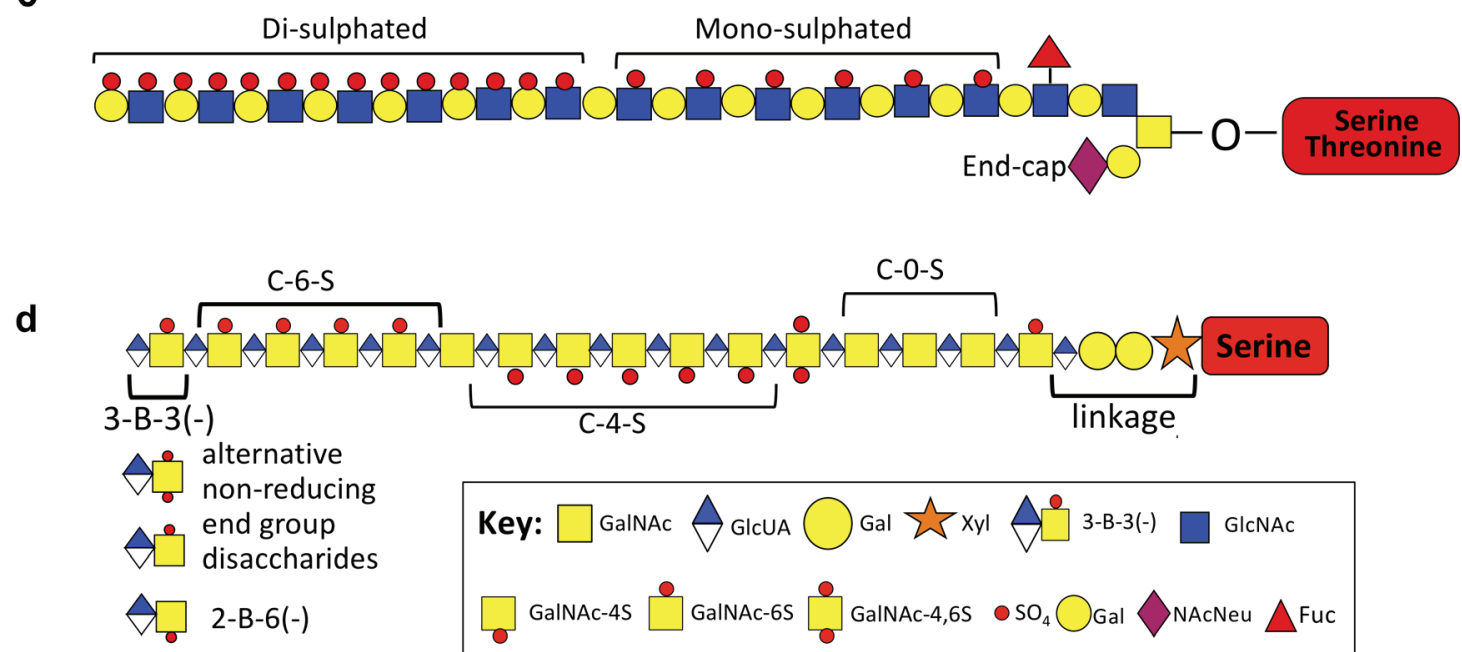

Fig. 1. Schematic depictions of the structural organisation of aggrecan, perlecan, and their KS-II and CS chains. These schematics should be viewed as generic depictions based on reported structural data. The depictions shown are for human (a) aggrecan and (b) perlecan; murine aggrecan has a truncated KS rich region and domain IV of murine perlecan also has a $40 \mathrm{kDa}$ truncation (Farach-Carson et al., 2014). (b) $\mathrm{N}$ - and O-sulphation positions of an HS disaccharide of perlecan in a highly modified region of the HS chain are also shown. Note: while perlecan is referred to as an HS-proteoglycan, intervertebral disc cells synthesise a hybrid form where at least one of the HS chains is replaced by a CS chain. (c) Typical regions of mono-, di- and non-sulphated regions of KS-II are shown along with possible fucosylation and neuraminic acid regions (Caterson and Melrose, 2018). (d) The CS disaccharides of aggrecan are heterogenous with regard to their sulphate distributions. 
IGD and the G2 and G3 domains are separated by an extended region. The extended region contains a KS attachment domain and $2 \mathrm{CS}$ attachment domains (CS-1, CS-2). During its synthesis, several O-linked oligosaccharides on the aggrecan core protein are extended to form KS chains, while CS is attached by a tetrasaccharide linkage region of GlcA-Gal-GalXyl. Several aggrecan molecules attach to HA by their G1 domains and LP, forming a supramolecule that holds a huge density of electro-negative charges (Fig. 1a,c,d). These charges attract water and ions into the disc compartment through the Gibbs-Donnan effect, creating a hyperosmotic niche within which the resident cells must survive (Silagi et al., 2018b).

Unlike human aggrecan, the murine aggrecan core protein is truncated and largely devoid of a KS-rich region. Complete sequencing of the murine core protein (Walcz et al., 1994; Watanabe et al., 1995) shows that it does not contain the consensus sequences for attachment of $\mathrm{KS}$ as found in human aggrecan core protein (E-(E,K)-P-F-P-S or E-E-P-(S,F)P-S) (Antonsson et al., 1989; Doege et al., 1991). Core protein sequencing data thus explains the reduced KS content of rodent aggrecan compared to other species (Stevens et al., 1984; Venn and Mason, 1985). While the KS-attachment region is shorter in murine aggrecan, some KS in the IGD of mouse aggrecan is thought to be present (Fosang et al., 2008). It should be noted that species-specific differences have been demonstrated in the amino acid sequences of the aggrecan IGD (Flannery et al., 1998). These differences can have consequences on the susceptibility of this region to proteolysis by ADAMTS-4/5 and MMPs (Lark et al., 1995; Little et al., 1999). Yet still, the mouse aggrecan core protein (222-259 kDa) shares $72.5 \%$ homology with human aggrecan, and the G1, G2, and G3 domains are homologous (Walcz et al., 1994; Watanabe et al., 1995). In addition, the spatio-temporal distribution of aggrecan in murine disc and cartilages is similar to that observed in humans, suggesting that murine aggrecan has similar weight-bearing roles in joint tissues despite the aforementioned subtle differences in structural organisation.

Some differences are also evident in the GAG substitution pattern of human and murine perlecan, the HS proteoglycan found in disc and cartilage (Knox et al., 2005; Melrose et al., 2003; Melrose et al., 2006). Perlecan has 5 domains, labelled I-V, where domains I and V may be substituted with HS or CS (Fig. 1b). Domain I, a domain unique to perlecan, is the main region of GAG substitution and contains a cluster of 3 potential attachment sites, while domain V has additional GAG attachment sites (Costell et al., 1997; Tapanadechopone et al., 1999). Furthermore, domain IV of mouse perlecan contains less IgG repeats than human perlecan. Consequently, its core protein is $\sim 40 \mathrm{kDa}$ smaller than the human counterpart (Kallunki and Tryggvason, 1992; Noonan et al., 1991). Mouse perlecan also contains an RGD cell attachment sequence in domain III, which is absent in human perlecan (Chakravarti et al., 1995), although a cell adhesion site in domain IV has been identified in human perlecan (Farach-Carson et al., 2008) indicating that the overall functionality of the molecule is preserved between the species.

While results obtained from murine IVDs should be interpreted with these points in mind and with regard to genetic background, the ease with which the mouse can be genetically manipulated and the abundance of knowledge the murine model has offered strongly outweighs the differences described above.

\section{Murine model systems \\ Transcription factors}

The formation of the notochord during embryonic development requires the coordinated action of many transcription factors (Tessier and Risbud, 2020). Among these, FOXA2 (Ang and Rossant, 1994), T (Stott et al., 1993), and NOTO (Ben Abdelkhalek et al., 2004) are instrumental as their absence results in failure of notochord formation and NP development. The loss of a notochord in FoxA2 null mice is lethal, precluding the study of FOXA1 and FOXA2 and their roles in IVD formation. Nevertheless, by using a conditional FoxA2 allele in conjunction with a tamoxifen inducible Cre allele $\left(S h h \mathrm{CreER}^{\mathrm{T} 2}\right)$, FoxA2 was removed from the notochord of E7.5 mice, which were also null for FoxA1. These double mutant animals had defects in the notochord sheath, severely deformed NP, increased cell death in the tail, decreased SHH signalling, and resultant disruption of dorsal-ventral patterning of the neural tube. Notably, embryos that were FoxA1 null or that had FoxA2 conditional deletion alone did not show abnormalities in the IVDs, demonstrating functional redundancy (Maier et al., 2013).

Once the embryonic spine has successfully developed, the maturing notochordal-NP cells produce a proteoglycan-rich matrix that creates a hyperosmotic niche for resident cells. Seminal studies conducted by Tsai et al. revealed that the osmoadaptive transcription factor, tonicity enhancer binding protein (TonEBP aka NFAT5 or OREBP), is required for survival of NP cells under these hyperosmotic conditions (Tsai et al., 2006). TonEBP modulates intracellular concentrations of organic osmolytes and the hyperosmotic environment by controlling the transcription of osmosensitive and matrix-related genes such as Slc6A6, Akr1b1, Aqp2, Acan, B3gat3, and Col2a1 (Gajghate et al., 2009; Johnson et al., 2014). TonEBP has also been shown to regulate pro-inflammatory genes including COX-2 (Choi et al., 2018a), IL-6, and C Cl2 (Johnson et al., 2016). The understanding of TonEBP in disc homeostasis has been elaborated upon by recent studies of TonEBPdeficient mice. While complete ablation of TonEBP is perinatally lethal with most embryos dying around E18.5, embryonic investigations have revealed that TonEBP loss causes developmental delay of the spinal column and aberrant levels of the notochord markers $\mathrm{SHH}, \mathrm{T}, \mathrm{CA} 3$, and vimentin. Interestingly, this study 
raised an interesting possibility that $\mathrm{SHH}$ receptor PTCH1 is a transcriptional target of TonEBP (Tessier et al., 2019). Subsequent studies of adult TonEBP haploinsufficient mice showed accelerated age-related disc degeneration and matrix fibrosis, with greater propensity for annular and endplate herniations. Moreover, TonEBP haploinsufficient mice displayed disc compartment-specific effects evidenced by increased expression of actin cytoskeleton-related genes in AF cells and reduced expression of immune and pro-inflammatory genes in NP cells (Tessier et al., 2020b).

An important determinant of the NP niche is its avascular and hypoxic nature. This notion of limited oxygen availability has led to the general belief that NP cells primarily produce energy via glycolysis with little dependence on mitochondrial metabolism. Remarkably, however, recent investigations of mitoQC reporter mice have conclusively shown that NP cells possess mitochondrial networks consisting of numerous tubular mitochondria which undergo increased mitophagy with aging, emphasising the importance of the mouse model as a key investigational tool. Furthermore, mitochondrial fragmentation, morphology, and mitophagic flux was shown to be mediated by HIF- $1 \alpha$ and mitochondrial receptor BNIP3 (Madhu et al., 2020).

Among its numerous functions, HIF- $1 \alpha$ regulates NP cell metabolism under hypoxic conditions by coordinating interactions between glycolysis and the TCA cycle (Madhu et al., 2020). HIF-1 $\alpha$ also contributes to the transmembrane balance of high intracellular $\mathrm{H}^{+}$and lactate concentrations by mediating expression of MCT4 (Silagi et al., 2020) and the bicarbonate recycling enzymes carbonic anhydrase 9 and 12 (Silagi et al., 2018a). MCT4 null mice show classical signs of disc degeneration with increased aggrecan degradation, elevated MMP13, and collagen $X$ levels (Silagi et al., 2020). As one would thus expect, analyses of the IVDs of HIF- $1 \alpha$ conditional knockout mice in either $\mathrm{SHH}$ or FOXA2 expressing cells has demonstrated early-onset postnatal degenerative features with notochordal cell loss and severely prominent fibrosis (Merceron et al., 2014; Wu et al., 2013). HIF-1 $\alpha$ also regulates galectin-3, a highly expressed lectin in the IVD. While its in vivo role in this tissue is poorly understood, in vitro studies suggest that galectin-3 promotes NP cell survival under conditions of oxygen deprivation. In NP cells, suppression of galectin-3 activity promotes the expression of FasL, an inducer of apoptosis, suggesting that this HIF- $1 \alpha$-regulated lectin plays a role in NP cell survival (Zeng et al., 2007). HIF-1 $\alpha$ and HIF-2 $\alpha$ have also been shown to negatively regulate the expression of ANK and thereby control local levels of pyrophosphate, an important inhibitor of tissue mineralisation (Skubutyte et al., 2010). Therefore, the hypoxic environment and the consequent role of HIF transcription factors is critical to the NP cell identify and function. The importance of low oxygen tension is further accentuated by recent investigations of
TNMD-null mice. TNMD is an anti-angiogenic factor with robust AF expression, especially by the outer annulocytes. Its loss $\left(\mathrm{Tnmd}^{-1-}\right)$, as well as a double knockout with its homologue, chondromodulin I $\left(\right.$ Tnm $\left.^{-/-} ; \mathrm{Chm}^{-H^{-}}\right)$, results in vascular invasion of the AF tissue, macrophage infiltration, and accelerated disc degeneration with hypertrophic cells. The double knockouts show greater progressive changes including ectopic bone formation (Lin et al., 2020).

Central regulators of spinal development and skeletogenesis include a number of SOX transcription factors. SOX9 and SOX5/6 have been shown to cooperate via super-enhancers to drive chondrogenesis (Liu and Eronique Lefebvre, 2015); hence, these three SOX proteins are often referred to as the SOX trio. The importance of the SOX family members is made apparent by the various human skeletal diseases caused by their heterozygous mutations. Mutation of a copy of Sox 9 or disturbance to its regulation causes campomelic dysplasia (Wunderle et al., 1998); haploinsufficiency of Sox5 causes LAMSHF, a neurodevelopmental disorder associated with variable skeletal abnormalities (Lamb et al., 2012). While SOX5/6 are functionally redundant, their dual ablation prevents formation of the notochord sheath, evidenced by notochordal and peri-notochordal downregulation of collagen II, versican, and aggrecan. These aberrations are also met by subsequent apoptosis of notochord cells and culminate in formation of a severely defective spine lacking NP (Smits and Lefebvre, 2003). Similarly, mouse embryos null for Sox9 show notochord disintegration as early as E9.5 (Barrionuevo et al., 2006) and deletion of Sox9 in the disc (AcanCre ${ }^{\mathrm{ERT} 2}$ So $x 9^{\mathrm{fl} / \mathrm{fl}}$ ) results in degeneration (Henry et al., 2012). Early degeneration of the CEP is the first conspicuous change seen in AcanCre ${ }^{\text {ERT2 }}$ Sox $9^{\mathrm{fl} / \mathrm{fl}}$ mice, followed by degeneration of all disc compartments and severe disc collapse involving apoptosis and progressive loss of disc cells. Importantly, transcriptomic profiling indicated that SOX9 has distinct compartmentspecific functions (Tsingas et al., 2020). The SOX trio also works with paired box transcription factors PAX1 and PAX9, which are essential for AF development (Peters et al., 1999; Sivakamasundari et al., 2017). Despite the key importance of the Sox genes in disc homeostasis and skeletogenesis, the precise roles that many of these transcription factors play in the adult disc remain elusive, representing a necessary avenue for future investigations.

In addition to PAX1/9 and the SOX trio, among others, the MKX and SCX transcription factors are key to AF development. Lineage tracing studies have shown that an AF multipotent progenitor population co-expressing SOX9 and SCX contribute to the formation of the inner and outer AF (Sugimoto et al., 2012). Furthermore, lineage studies have revealed that SCX-expressing cells drive AF regeneration after annular puncture of neonatal discs. This finding offers an interesting direction for future disc regeneration therapies, highlighting the importance of genetic 
lineage tracing studies in mice (Torre et al., 2018; Torre et al., 2019). By a similar token, complete knockout of $M k x$ results in smaller collagen fibril diameter in the outer AF and early onset disc degeneration. Transplantation of MKX-overexpressing MSCs into the injured AF of a tail-loop mouse model was shown to promote AF regeneration with abundant collagen fibril formation (Nakamichi et al., 2016). It is worth noting here that mice deficient in the transcription factor $\mathrm{BACH}-1$ are less impacted by annular puncture. BACH-1 deficiency results in increased levels of HO-1, which protects disc cells from oxidative stress (Ohta et al., 2012).

Recent investigations by Alvarez-Garcia et al. revealed that all compartments of the IVD express FOXO1, FOXO3, and FOXO4. Downregulation of FOXO levels, notably FOXO1 and FOXO3, was observed during aging, preceding major degenerative changes seen on histology (AlvarezGarcia et al., 2017). Simultaneous knocking out of these three FOXO isoforms using Col2a1Cre resulted in a progressive increase in NP cellularity, due to increased proliferation, and an associated increase in disc height. By 4 and 6 months, these discs began to show marked features of degeneration and a severe kyphosis. Interestingly, analysis of AcanCre $\mathrm{CRT2}^{\text {ERT }}$ driven triple knockout at skeletal maturity showed degenerative changes more conspicuous in the NP than the AF, while analysis of single gene knockouts showed that FOXO1 and FOXO3 are the dominant members, playing a role in mediating autophagy and antioxidant defences in NP tissues (Alvarez-Garcia et al., 2018).

Development of the axial skeleton relies on the tight spatio-temporal control of HOX transcription factors. The Hox genes that encode these factors differentially control the proliferation rates of the mesenchymal condensations that give rise to the vertebral cartilages. For instance, mutations in the homeobox containing gene Hoxb-4 (Hox 2.6) causes overt changes in the axial skeleton that are characterised by a transformation of the second cervical vertebra from axis to atlas (Ramfrez-Solis et al., 1993). Similarly, Hoxd-3 gene (Hox-4.1) disruption causes anterior transformations of the atlas and axis and a drastically remodelled craniocervical joint (Condie and Capecchi, 1993). The Hox10 and Hox11 genes are also involved in the global patterning of the axial and appendicular skeleton. Lumbar vertebrae fail to develop with loss of Hox10, while loss of Hox11 results in formation of lumbar vertebrae in the place of sacral vertebrae (Wellik and Capecchi, 2003).

\section{Cell signalling pathways}

An intricate balance of morphogenic signals is required for proper embryonic development of the IVD. A centrally important morphogen in this process is notochord-secreted $\mathrm{SHH}$, which not only patterns surrounding embryonic structures such as the neural tube and AF anlagen, but is also required for maintenance of the notochord itself and subsequent formation of the NP. Hedgehog proteins interact with the 4,6-disulphated non-reducing terminal glycans of CS chains in aggrecan and the HS chains of perlecan and this may localise $\mathrm{SHH}$ in tissues, aid in the formation of $\mathrm{SHH}$ gradients, and regulate $\mathrm{SHH}$ cell signalling (Bandari et al., 2015; Cortes et al., 2009; Ortmann et al., 2015).

The necessity of $\mathrm{SHH}$ for disc development was demonstrated by Choi and Harfe who removed SHH signalling from Shh-expressing cells, including the notochord and floorplate, using a floxed mouse allele of the $\mathrm{SHH}$ receptor Smo and ShhGFPcre (Choi and Harfe, 2011). Conditional ablation of Smo during early embryogenesis resulted in defects in IVDs and vertebrae formation; however, removal of Smo once the notochord sheath had formed did not alter disc development, highlighting the importance of the notochord sheath during spinal patterning. The role of SHH in IVD development and postnatal homeostasis has been investigated and reviewed by Dahia and colleagues (Rajesh and Dahia, 2018).

The function of WNT/ $\beta$-catenin signalling in the regulation of IVD development and degeneration has been examined in $\mathrm{WNT} / \beta$-catenin reporter (TOPGAL) mice (Dahia et al., 2009; Kondo et al., 2011). It was noted that during embryonic stages, WNT signalling was active in the CEPs and AF but very low in the NP. Postnatally, however, WNT signalling by NP cells was found to increase. Overexpression of $\beta$-catenin in both Col1a1 and Col2a1-expressing disc cells resulted in AF disorganisation, hyperplasia, and osteophyte formation in adult mice (Kondo et al., 2011; Wang et al., 2012). Deletion of $\beta$-catenin in Col2a1-expressing cells in 5-day-old mice resulted in accelerated maturation of subchondral bony endplate by 9 weeks of age. A later study using TOPGAL mice showed that WNT signalling in the NP declines with aging in both lumbar and caudal discs (Holguin et al., 2014). Of note, WNT signalling positively regulates $\mathrm{SHH}$, which activates the expression of differentiation factors and cell proliferation in NP cells, but undergoes a decline with IVD maturation (Winkler et al., 2014). WNT and SHH are poorly soluble proteins and in order to establish gradients of these morphogenetic components in tissues, perlecan may have a transporter role. Indeed, WNT binds to the LDL receptor-like domains of perlecan domain II (Matsuo and Kimura-Yoshida, 2014).

Growth factors stimulate matrix production and NP cell proliferation. CTGF, aka CCN2, serves key functions in this regard. CCN2 binds to LDL receptor LRP6, which is homologous to domain II of perlecan (Segarini et al., 2001), as well as integrins $\alpha 5 \beta 1$ and $\alpha \mathrm{v} \beta 5$ (Tran et al., 2014). CCN2 modulates BMP, TGF- $\beta$, and WNT signalling to coordinate chondrogenesis and angiogenesis during skeletal development (Abreu et al., 2002; Mercurio et al., 2004), and more recently in the prevention of degenerative disc disease (Matta et al., 2017). Deletion of the Ccn2 gene in notochord-derived cells results in ageassociated degeneration of IVDs, decreased levels 
of aggrecan and collagen II, and increased levels of collagen I within the NP (Bedore et al., 2013; Tran et al., 2013). The ability of CCN2 to regulate the composition of the IVD suggests that it may be a clinical target for the treatment of IVD degeneration.

The TGF- $\beta$ superfamily are secreted proteins that play crucial roles in the determination of the notochord lineage and in skeletal development, growth, and cell differentiation. The importance of these signalling proteins in IVD development was well-demonstrated by the constitutive conditional knockout of the TGF- $\beta$ type II receptor (Col $2 a$ Cre; $T g f b r 2^{\mathrm{fl} / \mathrm{fl}}$ ). These mutant embryos showed vertebrae deformities and IVDs that were either completely lost or reduced due to AF defects (Baffi et al., 2004; Baffi et al., 2006). Subsequent microarray analyses of the embryonic Tgfbr2-null discs revealed that the expression profiles were similar to that of vertebrae profiles (Sohn et al., 2010), and identified the transcription factor, avian erythroblastosis virus E-26 oncogene homologue (ERG), as a player in AF differentiation. Accordingly, the function of TGF- $\beta$ in disc development is thought to involve the induction of AF differentiation from the sclerotome while inhibiting chondrocyte differentiation of the presumptive IVD. More recently, Acan $\mathrm{Cre}^{\mathrm{ERT} 2} ; \mathrm{Tgfbr} 2^{\mathrm{fl} / \mathrm{fl}}$ mice were generated to study the role of Tgfbr2 in adult tissue. Deletion of Tgfbr 2 at 2 weeks-of-age resulted in progressive degeneration underscored by disorganisation of AF lamellae with thinning of AF collagen bundles, delayed bony endplate formation, and dystrophic calcification of the disc by 12 months of age (Alkhatib et al., 2018). These studies highlight that TGF- $\beta$ also plays a clear role in IVD homeostasis postnatally.

TGF- $\beta$ signals through SMAD3 and AP-1, positively regulating CCN2 expression in the NP and may represent a limited reparative response in IVD degeneration (Tran et al., 2010). Smad3 null mice are smaller in size, show spinal malformations and kyphosis, exhibit alterations in CEP structure, and show decreased IVD proteoglycan and collagen content (Li et al., 2009). TGF- $\beta / S M A D 3$ signalling in NP cells regulates the expression of $\beta-1,3-$ glucuronosyltransferase-1 (GlcAT-1), an important regulator of GAG synthesis, which may partly explain the reduced GAG levels in SMAD3 knockout mice (Wu et al., 2012). It may be concluded that CCN2 and TGF- $\beta 1$ are actively secreted by notochordal cells and that these direct resident disc cell populations in the maintenance of IVD homeostasis.

Additional growth factors that have a key role to play in disc homeostasis include IGF-1, FGF, and GDF5. IGF-1 and its receptor (insulin-like growth factor-1 receptor, IGF1R) have regulatory roles over extracellular matrix (ECM) synthesis and crucial roles in the maintenance of IVD homeostasis. IGF1 and TGF- $\beta 1$ both regulate MMP-2 production by NP cells (Pattison et al., 2001). The IVDs of $\mathrm{IGF}^{+/-}$mice display greater histopathological scores of degeneration, reduced collagen II and proteoglycan levels, and elevated MMP13 (Li et al., 2013). Aberrations to FGF-FGFR signalling are responsible for a diverse group of skeletal disorders including those that afflict the axial skeleton (Table 3). Polymorphism in GDF5 has been associated with disc degeneration in humans (Huang et al., 2018); accordingly, IVDs in GDF5 knockout mice show decreased proteoglycan content and loss of water binding, evident from reduced T2-weighted signal intensity of lumbar levels (Li et al., 2004).

Mutations in genes that cause over-stimulation of signalling pathways involved in cell growth and differentiation often yield predispositions to oncogenesis and other clinical pathologies, including skeletal abnormalities. Mutations in Nf1, which encodes neurofibromin, a GTPase-activating protein that downregulates the RAS pathway, causes NF1. NF1 is a disorder characterised by generalised focal bony lesions, dystrophic scoliosis, and tibial pseudoarthrosis. To investigate the aetiology of the skeletal abnormalities associated with NF1, researchers used Col2a1Cre; $N f 1^{\mathrm{fl} / \mathrm{fl}}$ mice to silence $N f 1$ in axial and appendicular osteochondroprogenitor cells. These mice displayed progressive scoliosis, kyphosis, short stature, and IVD defects, closely recapitulating the clinical features of NF1 in human patients. Interestingly, inhibition of RAS/ERK by lovastatin mitigated the phenotype of these mice, suggesting that activation of the RAS/ERK pathway by NF1 loss-of-function is in part responsible for these spinal defects (Wang et al., 2011). Similarly, tuberous sclerosis complex (TSC) is an autosomal dominant disorder characterised by mutations in Tsc1 or Tsc2 that leads to hyperactivation of mTOR. Patients with TSC suffer from benign tumours known as tubers that affect several organ systems including sclerotic bone lesions. Tsc1 null mice show congenital spinal defects marked by kyphosis and a degenerative disc phenotype (Yang et al., 2017). Recent studies of PHLPP1, a phosphatase that negatively regulates Akt signalling, suggested that this axis may play a role in disc degeneration. Disc injury in Phlpp1 null mice lead to Akt activation and cell proliferation and showed long-term positive effects on preserving cellularity and matrix homeostasis, implying that it can be explored as a therapeutic target (Zhang et al., 2019). Ulici et al. have also recently reported the skeletal phenotype of JNK1 and JNK2 doubleknockout mice (Col2a1Cre; Jnk1 $1^{\mathrm{f} / \mathrm{fl} /} / J n k 2^{--}$). These mice showed a severe and early onset scoliotic phenotype and vertebral and disc fusions (Ulici et al., 2019).

A murine model of human progeroid syndrome was developed by genetic ablation of Ercc1, a gene that encodes a functional protein of the XPF-ERCC1 nuclease, ERCC1 (Niedernhofer et al., 2006) and contributes to the repair of double stand breaks. Haploinsufficient Ercc1 show advanced degenerative changes in the vertebral bodies and IVDs, including reduced proteoglycan content, increased apoptosis, and p16 positive cells, consistent with accelerated 
senescence and aging (Vo et al., 2010). Further studies linked NF- $\mathrm{BB}$-mediated signalling to the $\mathrm{Ercc}^{+/-}$ phenotype (Nasto et al., 2012).

\section{Extracellular matrix and its turnover}

In a polyaxial diarthrodial joint, the disc allows the spine to flex, extend, and rotate, with the NP functioning as a central fulcrum (Shapiro et al., 2012). This system is made possible by the relationship between the swelling forces of the NP due to its proteoglycan-rich matrix and opposing counterforces provided by the concentric collagenous lamellae of the AF. Therefore, matrix changes and degradation often define degenerative disc pathology (Table 2).

High concentrations of aggrecan and HA are characteristic features of the IVD. Mice lacking HAS2 show prominent vertebral body defects underscored by a lack of endochondral ossification, decreased matrix deposition, and increased cartilage cellularity. Perhaps counter to what one might expect, NP cellularity was increased with copious vacuolated cells. Since HA can interact with chondrocytes through CD44, RHAMM, and other cell surface receptors, it is possible that lack of HA induced a state of proliferation and differentiation in the targeted cells of these mice (Roughley et al., 2011).

Chloe B6 mice have a knock-in mutation in the Acan gene that changes the sequence in the IGD from DIPEN $\downarrow$ FFG to DIPEN $\downarrow$ GTR for the purpose of blocking MMP-dependent cleavage of aggrecan (Little et al., 2005). These mice do not show major alterations in skeletal development, and their IVDs have no obvious developmental abnormalities. ADAMTS-5 is the major aggrecan degrading metalloprotease in murine articular cartilage and disc (Stanton et al., 2005), while ADAMTS-4 is the major aggrecanase in murine growth plates (Glasson et al., 2005). ADAMTS-4 knockout mice, surprisingly, do not show any defects in skeletal development, growth, or remodelling, and no alterations in the growth of their long bones (Glasson et al., 2004). Likewise ADAMTS-5 knockout mice have no skeletal developmental abnormalities, although deletion of ADAMTS- 5 effectively prevents cartilage destruction in a murine osteoarthritis model and is shown to protect from chronic tobacco smoke-induced disc degeneration (Ngo et al., 2017). These findings are consistent with the view that ADAMTS-5 is largely responsible for the turnover of murine aggrecan

Table 2. Mouse models involving mutations in spine ECM molecules.

\begin{tabular}{|c|c|c|}
\hline Model & Phenotype & References \\
\hline HAS2 knockout & Vertebral body defects, decreased matrix deposition, and increased cartilage and NP cellularity. & Roughley et al., 2011 \\
\hline Chloe B6 mice & No obvious abnormalities. & Little et al., 2005 \\
\hline Perlecan knockout & $\begin{array}{l}\text { Shortened growth plates, defective endochondral ossification leading to dwarfism, severe chondrodysplasia, } \\
\text { dyssegmental ossification of spine. Generalised abnormalities in development of vasculature and musculoskeletal } \\
\text { system, myotonia. }\end{array}$ & $\begin{array}{l}\text { Arikawa-Hirasawa et } \\
\quad \text { al., } 1999\end{array}$ \\
\hline PRG4 knockout & Increased torsional modulus and reduced transverse major diameter and height. & Teeple et al., 2015 \\
\hline BGN knockout & Premature osteoarthritis and early-onset disc degeneration involving both the NP and AF. & Furukawa et al., 2009 \\
\hline COL2A1 deficiency & $\begin{array}{l}\text { Homozygous null: Severe skeletal defects and inability to pattern the notochord during disc development. } \\
\text { Haploinsufficiency: Early skeletal defects including shorter spines, thicker and irregular vertebral endplates, and } \\
\text { lower GAG levels in the AF. }\end{array}$ & $\begin{array}{l}\text { Aszódi et al., } 1998 \\
\text { Sahlman et al., } 2001\end{array}$ \\
\hline COL9A1 knockout & $\begin{array}{l}\text { Premature degeneration associated with physical impairment and degenerative changes in the disc including the } \\
\text { CEP. }\end{array}$ & $\begin{array}{l}\text { Allen et al., } 2009 \\
\text { Boyd et al., } 2008 \\
\text { Goldring, } 2009 \\
\end{array}$ \\
\hline ADAMTS-4 knockout & No obvious skeletal phenotype. & Glasson et al., 2004 \\
\hline ADAMTS-5 knockout & Protective against cartilage destruction and chronic tobacco smoke induced disc degeneration. & Ngo et al., 2017 \\
\hline MT1-MMP knockout & $\begin{array}{l}\text { Inadequate collagen turnover, dwarfism, kyphosis, accelerated age-related osteoarthritic changes evident in axial } \\
\text { skeleton. }\end{array}$ & Holmbeck et al., 1999 \\
\hline SPARC knockout & $\begin{array}{c}\text { Endplate calcification and sclerosis. Elevated cell numbers in the AF, greater incidence of AF herniations. } \\
\text { Behavioural studies evidence pain. }\end{array}$ & $\begin{array}{l}\text { Gruber et al., } 2005 \\
\text { Millecamps et al., } 2012\end{array}$ \\
\hline Thrombospondin-2 knockout & $\begin{array}{c}\text { Impaired collagen fibrillogenesis, reduced levels of transglutaminase, fragile skin, and disorganisation of annular } \\
\text { lamellae. }\end{array}$ & Gruber et al., 2008 \\
\hline
\end{tabular}

Table 3. Mouse models examining aberrant FGF-FGFR signalling effects on spinal development.

\begin{tabular}{|c|c|c|c|}
\hline Model & Mechanism & Phenotype & References \\
\hline Ectopic FGF-2 expression & FGF-2 transgene & Skeletal dwarfism & Coffin et al., 1995 \\
\hline FGF-2 deficient mouse & Knockout mutation & Inhibition of bone formation/bone mass \\
\hline Apert Syndrome FGF2(+/S252W) mouse & FGF-2 knock-in & Abnormalities in cartilage and bone development \\
\hline Ectopic FGF-9 expression & FGF-9 transgene & Achondroplasia like dwarfism & Wang et al., 2005 \\
\hline FGFR3 deficient mice & Knockout mutation & Skeletal overgrowth & Colvin et al., 1996 \\
\hline DGFR3 et al., 1996
\end{tabular}


in-vivo (Glasson et al., 2005). ADAMTS-5-dependent aggrecanolysis predominates over ADAMTS-4 in mouse cartilaginous tissues due to an absence of highly sulphated KS chains in the murine IGD (Stanton et al., 2005; Stewart et al., 2006). These mutants suggest that preventing aggrecan turnover do not lead to major effects on skeletogenesis and disc health.

Naturally occurring and engineered mutations in the gene encoding perlecan (Hspg2) show unequivocally that perlecan is essential for cell growth, differentiation, and the function of cartilaginous tissues (Arikawa-Hirasawa et al., 1999; Arikawa-Hirasawa et al., 2001). Both the core protein and the GAG chains confer perlecan's ability to modulate these processes. When substituted with HS, perlecan domain I promotes binding to laminin-1 and collagen IV. Perlecan can also interact with a number of fibrillar or cell attachment molecules in the ECM and thus plays important roles in its organisation (Melrose et al., 2008). The HS side chains of domain I of perlecan act as low affinity co-receptors for growth factors, such as FGF-1, -2, -7 and -9 , and a core protein receptor for FGF-7 has also been reported (Ghiselli et al., 2001; Mongiat et al., 2000). This complex formation is important for the correct presentation of the FGFs to FGFRs, their subsequent oligomerisation, activation to initiate cell signalling through the cytoplasmic tail of the FGFRs, and subsequent downstream effects on cell proliferation and differentiation (Chang et al., 2000; Chuang et al., 2010; Knox et al., 2001; Knox and Whitelock, 2006). Perlecan contains multiple modules that are homologous to the LDL receptor (Murdoch et al., 1992; Noonan et al., 1991). When expressed on cells, domain II of perlecan binds and internalises LDL in a similar manner to LRP6 (Fuki et al., 2000). The development of perlecan gene knock-out mice has demonstrated the essential role played by perlecan in cartilage development and skeletogenesis. Homozygous knockout mice, which survive to birth, display severe skeletal defects with short axial and limb bones, defects of vertebral ossification centres, cleft palate, and striking abnormalities in the growthplates of their long-bones (Arikawa-Hirasawa et al., 1999).

Null mice for the proteoglycans PRG4 and BGN have also been generated. Biomechanical studies of PRG4 knockout spines have revealed an increased torsional modulus, and disc dimension measurements suggest that null discs have a reduced transverse major diameter and height, with an NP that takes up a relatively larger area of the disc (Teeple et al., 2015). BGN is a SLRP that contributes to collagen fibrillogenesis, control of the bioavailability of TGF- $\beta$ activity, and cellular regulation. Consequently, BGN knockout mice display premature osteoarthritis and early-onset disc degeneration involving both the AF and NP (Furukawa et al., 2009).

In addition to proteoglycans, collagens are major matrix constituents of the disc matrix. Inactivation of COL2A1 leads to premature ossification and IVD degeneration. One-month-old Col2a1 (+/-) mice have shorter spines, thicker and irregular vertebral endplates that calcify prematurely, and lower GAG levels in the AF. By 15 months, some compensation in these spinal changes occur (Sahlman et al., 2001). Homozygous transgenic mice lacking COL2A1 die at birth and show severe skeletal defects characterised by impaired endochondral ossification and an inability to pattern the notochord during disc development (Aszódi et al., 1998).

Collagen IX is a nonfibrillar collagen composed of three gene products: alpha-1(IX), alpha-2(IX), and alpha-3(IX). Collagen IX molecules are localised on the surface of type II-containing fibrils and consist of two arms. These include a long arm that is crosslinked to collagen II and a short arm that projects into the perifibrillar space (Diab et al., 1996). It has been proposed that collagen IX molecules are involved in the interaction of fibrils with each other or with other components of the ECM. A mouse lacking both isoforms of the alpha-1(IX) chain has been developed (Col9a1 null). Col9a1 null mice do not show evident abnormalities at birth, but progressively develop marked joint degeneration as is seen in osteoarthritis. Col9a1 null mice also develop premature degeneration associated with physical impairment and degenerative changes in the disc, including the CEPs. Behavioural studies measuring reflexes, beam walking, pole climbing, wire-hanging, grip strength, sensorimotor skills, and mechanical and thermal pain sensitivity were all compromised in these knockout mice (Allen et al., 2009; Boyd et al., 2008; Goldring, 2009).

Interestingly, while preventing aggrecan turnover in murine tissues does not result in major phenotypes, blocking collagen turnover in some mouse models can have severe effects on skeletogenesis (Glasson et al., 2004; Holmbeck et al., 1999; Little et al., 2005). Mouse strains deficient in MMP-1, $-2,-3,-7,-8,-9$, and -12 have been developed (Bian et al., 2016; Foley and Kuliopulos, 2014; Van Hove et al., 2016; Kato et al., 2015; Robinson et al., 2003; Wells et al., 2003; Wilson et al., 1999). While some changes in haematopoiesis and angiogenesis associated with the maturation of long bone growth plates have been reported in some of these models, little or no impairment in skeletal development has been observed. The contributions of individual enzymes and functional overlap with other MMPs is therefore important to take into consideration. In contrast, membrane type-1 MT1-MMP (aka MMP-14) knockout mice display cervical kyphosis, disc degeneration, and accelerated age-dependent osteoarthritic changes in the axial skeleton. This is apparently due to inadequate collagen turnover, which emphasises the critical role MT1-MMP plays in the conversion of MMPs from their inactive precursors into their active forms to promote collagenolysis in-situ (Holmbeck et al., 1999). Likewise, MMP13 efficiently cleaves collagen II. MMP13 knockout mice display significant accumulation of interstitial collagen in their growth 
plate cartilages and delayed endochondral ossification due to inefficient collagen turnover (Inada et al., 2004; Stickens et al., 2004). Its abundant presence in severely degenerated discs also highlights the deleterious role MMP13 can play in pathological states.

Matricellular proteins have emerged as important regulators of cell-ECM interactions and a growing body of evidence has established roles for these proteins in disc homeostasis. SPARC is a matricellular protein important in the maintenance of IVD integrity. Radiological examination of spines from 2-month-old SPARC knockout mice revealed wedging, endplate calcification, and sclerosis. At 3 months onwards, SPARC knockout mice showed elevated cell numbers in the AF and a greater incidence of AF herniations. Aged SPARC knockout mice mirrored aspects of low back pain as they displayed changes in cutaneous sensitivity to cold, heat, mechanical stimuli, and ambulation, indicating pain may be emanating from the disc (Gruber et al., 2005; Millecamps et al., 2012). Similarly, mice with disruption of the gene encoding thrombospondin-2, a multifunctional, anti-angiogenic matricellular protein, showed impaired collagen fibrillogenesis, reduced levels of the intermolecular cross-linking enzyme transglutaminase, fragile skin, and disorganisation of annular lamellae (Gruber et al., 2008).

Ectopic calcification is a notable feature that is known to occur in several spinal disorders. Mice lacking ENT1, a model of diffuse idiopathic skeletal hyperostosis, show reduced expression of ANK, ENPP1, and ALPL in discs, increased AF cell proliferation, and progressive ectopic calcification of fibrous connective tissues along the spine (Warraich et al., 2013). Analyses of AF tissue isolated from ENT1 knockout mice has further revealed that the observed increased cell proliferation is associated with an upregulation of E2F transcription factors, the cell cycle regulators RB1 and CDK2, and stimulation of the JNK/MAPK pathway (Veras et al., 2019). Notably, the importance of genetic background in the ectopic calcification process has been recently demonstrated by the study of LG/J inbred mice, which show an agedependent increase in dystrophic mineralisation of discs (this mouse strain will be discussed later in the review) (Novais et al., 2020).

An evolving view of inflammation in disc degeneration An association between increased inflammation and IVD degeneration is well-described and most commonly attributed to the cytokines TNF $\alpha$ and IL-1 $\beta$. Nevertheless, investigations of human TNF $\alpha$ overexpressing mice (Tg197 and hTNF $\alpha \mathrm{Tg}$ ) and IL- $1 \alpha / \beta$ double knockout (IL-1 KO) mice have led to questioning the understanding of the role inflammation plays in disc homeostasis. While polyarthritic Tg-hTNF mice show compromised vertebral bone parameters, AF defects, and a greater propensity for herniations at the CEP/ AF junction, the presence of increased TNF- $\alpha$ in these mice did not show adverse effects on the NP compartment. Surprisingly, Tg-TNF mice showed healthy-appearing NP cells that assembled into an expanded cell band and the overall transcriptomic profile remained unaltered (Gorth et al., 2018; Gorth et al., 2020). This phenotype contradicts the existing view that chronic TNF $\alpha$ overexpression would cause pronounced disc degeneration, as the articular joints of these mice are severely degenerated by rheumatoid arthritis. Plausible reasons for this phenotype could be that previous studies have exclusively used herniated human disc material with infiltrated immune cells as starting material for the analysis, shaping the understanding of the function of TNF $\alpha$ in the disc compartment. This phenomenon, in which differential effects of inflammation are observed in discs as opposed to articular cartilage, has also been noted in TonEBP haploinsufficient mice. TonEBPdeficient NP cells downregulate pro-inflammatory molecules yet experience notable degeneration, while, on the other hand, TonEBP-deficiency is protective against immune-driven arthritis (Tessier $e t$ al., 2020b). The differential effects of inflammation on these joints may be credited to the fact that the inner disc is largely avascular and immune privileged, unless penetrated by herniation. Similarly, while conditional loss of $\mathrm{p} 16^{\text {Ink4a }}$ (AcanCreER $\left.{ }^{\mathrm{T} 2} ; \mathrm{p} 16 \mathrm{Ink}_{4} \mathrm{a}^{\mathrm{f} / \mathrm{f}}\right)$ shows lower NP levels of IL-1 $\beta$, IL-6, and MCP-1, these mice are not protected from age-dependent degenerative changes (Novais et al., 2019). Global IL- $1 \alpha / \beta$ double knockout mice also show higher degenerative grades with aging than wild-type counterparts, suggesting that loss of IL-1 does not serve a protective role (Gorth et al., 2019). Seemingly contrary to the phenotype of these IL-1 knockout mice, mice null for the IL-1rn gene were reported to develop spinal abnormalities (Phillips et al., 2013). However, the discrepancies in these findings may be reflective of mouse strain-dependent effects (C57BL/6, IL-1KO; BALB/c, IL-1rnKO), highlighting the complexity of inflammation on disc health.

\section{The cytoskeleton}

The cytoskeleton is fundamental to cell biology as it maintains intracellular organisation and cell shape, offers mechanical support, and links the cell to extracellular components by transmembrane proteins to enable functions such as cell adhesion and migration. Although this critical component of the cell is largely understudied in IVD tissues, a few mouse models targeting the cytoskeleton have been developed. These include mice lacking ARP2/3, the branched actin nucleator, and FLNB, an actin-binding protein which forms a linking scaffold to coordinate signal transduction (Table 4).

Constitutive deletion of the Arpc2 gene encoding a critical subunit of the ARP $2 / 3$ complex in collagen II-expressing cells (Col2a1-Cre; Arpc $2^{\mathrm{f} / \mathrm{f} / \mathrm{I}}$ ) results in severe chondrodysplasia and spinal defects. These mice are dwarfed due to disorganised growth plates, present with kyphosis, and show dramatic changes to the IVDs, some of which are fused. On histology, 
Table 4. Mouse models with mutations in cytoskeleton genes.

\begin{tabular}{|c|c|c|}
\hline Model & Phenotype & References \\
\hline $\begin{array}{c}\text { Col2a1-Cre; } \\
\text { Arpc2 }^{\text {f/f }}\end{array}$ & $\begin{array}{c}\text { Severe chondrodysplasia, spinal defects, } \\
\text { dwarfism, growth plate expansion, } \\
\text { deformation of AF and NP compartments, } \\
\text { fused discs. }\end{array}$ & Tessier et al., 2020a \\
\hline $\begin{array}{c}\text { Acan-CreER } \\
\text { Arpc2 } 2^{\text {f/f }}\end{array}$ & $\begin{array}{c}\text { NP cell-band expansion and AF degeneration } \\
\text { marked by altered matrix composition. }\end{array}$ & Tessier et al., 2020a \\
\hline $\begin{array}{c}\text { FLNB } \\
\text { knockout }\end{array}$ & $\begin{array}{c}\text { Postnatal progressive disc degeneration, } \\
\text { endochondral-like ossification of AF, vertebral } \\
\text { fusions. }\end{array}$ & Zieba et al., 2016 \\
\hline
\end{tabular}

the growth plates are grossly expanded, the NP is reduced in size, and the AF is deformed and disorganised, containing rounded chondrocyte-like cells. Embryonic and postnatal lethality in these mice led to the crossing of $A r p c 2^{\mathrm{f} / \mathrm{fl}}$ with the inducible Acan$\mathrm{CreER}^{\mathrm{T} 2}$ allele to generate $A$ can-CreER ${ }^{\mathrm{T} 2} ; A r p c 2^{\mathrm{f} / \mathrm{fl}}$ mice. Resultant loss of ARP2/3 at skeletal maturity was shown to induce notable AF degeneration marked by altered matrix composition. In vitro analyses further revealed that ARP2/3 controls TonEBP-dependent osmoadaptation and cell-ECM interactions in NP cells (Tessier et al., 2020a).

Similarly, the discs of $\mathrm{FLNB}^{-/}$mice show rapid and progressive degeneration during postnatal development. The AF cells of these mice undergo differentiation into the chondrogenic lineage, acquiring the signature of hypertrophic chondrocytes and upregulating TGF $\beta$ and BMP signalling. Consequently, AF tissues show endochondrallike ossification, express collagen $X$, and evidence increased apoptosis, leading to vertebral fusions (Zieba et al., 2016). Loss-of-function of other factors known to influence the cytoskeleton such as $N$-cadherin and $\alpha_{v} \beta_{6}$ integrin have also been investigated in mice and are associated with altered disc cell morphology and degenerative phenotypes (Bian et al., 2017; Hwang et al., 2016).

Nuclear HS-proteoglycans such as perlecan have recently been identified in NP cells. These may interact with cytoskeletal components and reorganise the nucleosome and chromatin organisation which may regulate the access of transcription factors to DNA (Hayes and Melrose, 2021; Kovalszky et al., 2014). Nuclear HS-proteoglycans inhibit histone deacetylases resulting in chromatin compaction affecting DNA accessibility to transcription factors. HS also inhibits DNA topoisomerase I activity, which has important roles to play in (1) the removal of DNA supercoils during transcription and DNA replication; (2) the re-annealing of DNA strands following strand breakage during re-combination and chromosomal condensation; and (3) the disentanglement of intertwined DNA strands during mitosis (Champoux, 2001; Wang, 2002). Nuclear heparanase may have roles in the regulation of nuclear HS-proteoglycans (Chen and Sanderson, 2009).

Insights from inbred mice

While genetically modified mice have offered important insights into the function of individual genes, recent investigations of inbred mouse strains (SM/J, LG/J, and C57BL/6) have provided invaluable lessons on the pathogenesis of disc degeneration. $\mathrm{SM} / \mathrm{J}$ (small) and LG/J (large) mice, generated by crossing multiple inbred strains and selecting for body size, are models of choice for QTL analysis. These strains show differential cartilage healing capacities: $\mathrm{SM} / \mathrm{J}$ is considered a poor healer strain whereas LG/J is considered a super healer. The SM/J is the first mouse model to show early onset and spontaneous disc degeneration without the need of overt, inflammation-causing injury such as annular puncture, tail looping, or mechanical overloading (Choi et al., 2018b; Zhang et al., 2018). Thus, the SM/J is proposed to more closely resemble the chronic disc degeneration seen in most humans. The disc phenotype of these mice has been characterised by matrix fibrosis, elevated markers of hypertrophic chondrocytes, increased NP cell death, decreased WNT and VEGF signalling, and dysregulated ion transport systems (Choi et al., 2018b; Zhang et al., 2018). An extensive characterisation and comparison of these inbred mice, as well as the commonly used C57BL/6J strain, during the aging process has been recently conducted by Novais et al. (2020). An important insight derived from these studies is the observation that each mouse strain possesses a unique disc degeneration phenotype, with dissimilar morphological features, transcriptomic signatures, and onset of disease. Strain-dependent differences at the gene expression and histological level following traumatic injury have also been recently demonstrated (Brent et al., 2020). Ultimately, these differences underscore the notion that disc degeneration is largely influenced by genetic background and therefore, when combined with environmental and mechanical factors, presents heterogeneously across individuals as sub-phenotypes.

\section{Conclusions}

With the advances in knowledge provided by the completion of the human genome project and elucidation of the complete murine genome, the mouse represents the vehicle of choice for further examining the role of specific human gene abnormalities on spinal development and homeostasis in health and disease. While the mouse musculoskeletal system displays notable differences, including the persistence of notochordal-NP cells, quadrupedalism, additional vertebrae, and some variations in the structure of proteoglycans, the mouse model nevertheless is an attractive experimental system to answer important questions in spinal pathobiology. Due to these intrinsic differences, careful interpretation of experimental findings is indicated when attempting to make comparisons with the human musculoskeletal system. The described studies on the mouse IVD have identified many potential therapeutic targets worthy of further 
examination, not only in the mouse, but also in other animal models, to ultimately identify their roles in human disc degeneration.

\section{Acknowledgements}

This study is supported by the grants from the National Institute of Arthritis and Musculoskeletal and Skin Diseases (NIAMS) R01AR055655, R01AR064733, and R01AR074813.

\section{References}

Abreu JG, Ketpura NI, Reversade B, De Robertis EM (2002) Connective-tissue growth factor (CTGF) modulates cell signalling by BMP and TGF- $\beta$. Nat Cell Biol 4: 599-604.

Adams P, Eyre DR, Muir H (1977) Biochemical aspects of development and ageing of human lumbar intervertebral discs. Rheumatol Rehabil 16: 22-29.

Aguiar DJ, Johnson SL, Oegema TR (1999) Notochordal cells interact with nucleus pulposus cells: regulation of proteoglycan synthesis. Exp Cell Res 246: 129-137.

Alkhatib B, Liu C, Serra R (2018) Tgfbr2 is required in Acan-expressing cells for maintenance of the intervertebral and sternocostal joints. JOR SPINE 1: e1025. DOI: 10.1002/jsp2.1025.

Allen KD, Griffin TM, Rodriguiz RM, Wetsel WC, Kraus VB, Huebner JL, Boyd LM, Setton LA (2009) Decreased physical function and increased pain sensitivity in mice deficient for type IX collagen. Arthritis Rheum 60: 2684-2693.

Alvarez-Garcia O, Matsuzaki T, Olmer M, Masuda K, Lotz MK (2017) Age-related reduction in the expression of FOXO transcription factors and correlations with intervertebral disc degeneration. J Orthop Res 35: 2682-2691.

Alvarez-Garcia O, Matsuzaki T, Olmer M, Miyata K, Mokuda S, Sakai D, Masuda K, Asahara H, Lotz MK (2018) FOXO are required for intervertebral disk homeostasis during aging and their deficiency promotes disk degeneration. Aging Cell 17: e12800. DOI: $10.1111 /$ acel.12800.

Ang SL, Rossant J (1994) HNF-3 $\beta$ is essential for node and notochord formation in mouse development. Cell 78: 561-574.

Antonsson P, Heinegård D, Oldberg A (1989) The keratan sulfate-enriched region of bovine cartilage proteoglycan consists of a consecutively repeated hexapeptide motif. J Biol Chem 264: 16170-16173.

Arikawa-Hirasawa E, Watanabe H, Takami H, Hassell JR, Yamada Y (1999) Perlecan is essential for cartilage and cephalic development. Nat Genet 23: 354-358.

Arikawa-Hirasawa E, Wilcox WR, Le AH, Silverman N, Govindraj P, Hassell JR, Yamada Y (2001) Dyssegmental dysplasia, Silverman-
Handmaker type, is caused by functional null mutations of the perlecan gene. Nat Genet 27: 431-434.

Aszódi A, Chan D, Hunziker E, Bateman JF, Fässler R (1998) Collagen II is essential for the removal of the notochord and the formation of intervertebral discs. J Cell Biol 143: 1399-1412.

Baffi MO, Moran MA, Serra R (2006) Tgfbr2 regulates the maintenance of boundaries in the axial skeleton. Dev Biol 296: 363-374.

Baffi MO, Slattery E, Sohn P, Moses HL, Chytil A, Serra R (2004) Conditional deletion of the TGF- $\beta$ type II receptor in Col2a expressing cells results in defects in the axial skeleton without alterations in chondrocyte differentiation or embryonic development of long bones. Dev Biol 276: 124-142.

Bandari S, Exner S, Ortmann C, Bachvarova V, Vortkamp A, Grobe K (2015) Sweet on Hedgehogs: regulatory roles of heparan sulfate proteoglycans in Hedgehog-dependent cell proliferation and differentiation. Curr Protein Pept Sci 16: 66-76.

Barrionuevo F, Taketo MM, Scherer G, Kispert A (2006) Sox9 is required for notochord maintenance in mice. Dev Biol 295: 128-140.

Ben Abdelkhalek H, Beckers A, Schuster-Gossler K, Pavlova MN, Burkhardt H, Lickert H, Rossant J, Reinhardt R, Schalkwyk LC, Müller I, Herrmann BG, Ceolin M, Rivera-Pomar R, Gossler A (2004) The mouse homeobox gene Not is required for caudal notochord development and affected by the truncate mutation. Genes Dev 18: 1725-1736.

Bedore J, Sha W, McCann MR, Liu S, Leask A, Séguin CA (2013) Impaired intervertebral disc development and premature disc degeneration in mice with notochord-specific deletion of CCN2. Arthritis Rheum 65: 2634-2644.

Bian F, Wang C, Tukler-Henriksson J, Pflugfelder SC, Camodeca C, Nuti E, Rossello A, Li DQ, de Paiva CS (2016) MMP-8 is critical for dexamethasone therapy in alkali-burned corneas under dry eye conditions. J Cell Physiol 231: 2506-2516.

Bian Q, Ma L, Jain A, Crane JL, Kebaish K, Wan M, Zhang Z, Edward Guo X, Sponseller PD, Séguin CA, Riley LH, Wang Y, Cao X (2017) Mechanosignaling activation of TGF $\beta$ maintains intervertebral disc homeostasis. Bone Res 5: 17008. DOI: 10.1038/ boneres.2017.8.

Boos N, Weissbach S, Rohrbach H, Weiler C, Spratt KF, Nerlich AG (2002) Classification of age-related changes in lumbar intervertebral discs: 2002 Volvo award in basic science. Spine (Phila Pa 1976) 27: 26312644.

Boyd LM, Richardson WJ, Allen KD, Flahiff C, Jing L, Li Y, Chen J, Setton LA (2008) Early-onset degeneration of the intervertebral disc and vertebral end plate in mice deficient in type IX collagen. Arthritis Rheum 58: 164-171.

Brent JM, Tian Z, Shofer FS, Martin JT, Yao L, Archete C, Chen YH, Qin L, Enomoto-Iwamoto M, Zhang Y (2020) Influence of genetic background and sex on gene expression in the mouse (Mus musculus) 
tail in a model of intervertebral disc injury. Comp Med 70: 131-139.

Bruehlmann SB, Rattner JB, Matyas JR, Duncan NA (2002) Regional variations in the cellular matrix of the annulus fibrosus of the intervertebral disc. J Anat 201: 159-171.

Caterson B, Melrose J (2018) Keratan sulfate, a complex glycosaminoglycan with unique functional capability. Glycobiology 28: 182-206.

Chakravarti S, Horchar T, Jefferson B, Laurie GW, Hassell JR (1995) Recombinant domain III of perlecan promotes cell attachment through its RGDS sequence. J Biol Chem 270: 404-409.

Champoux JJ (2001) DNA topoisomerases: Structure, function, and mechanism. Annu Rev Biochem 70: 369-414.

Chang Z, Meyer K, Rapraeger AC, Friedl A (2000) Differential ability of heparan sulfate proteoglycans to assemble the fibroblast growth factor receptor complex in situ. FASEB J 14: 137-144.

Chen L, Sanderson RD (2009) Heparanase regulates levels of syndecan-1 in the nucleus. PLoS One 4: e4947. DOI: 10.1371/journal.pone.0004947.

Choi H, Chaiyamongkol W, Doolittle AC, Johnson ZI, Gogate SS, Schoepflin ZR, Shapiro IM, Risbud MV (2018a) COX-2 expression mediated by calcium-TonEBP signaling axis under hyperosmotic conditions serves osmoprotective function in nucleus pulposus cells. J Biol Chem 293: 8969-8981.

Choi H, Tessier S, Silagi ES, Kyada R, Yousefi F, Pleshko N, Shapiro IM, Risbud MV (2018b) A novel mouse model of intervertebral disc degeneration shows altered cell fate and matrix homeostasis. Matrix Biol 70: 102-122.

Choi KS, Harfe BD (2011) Hedgehog signaling is required for formation of the notochord sheath and patterning of nuclei pulposi within the intervertebral discs. Proc Natl Acad Sci U S A 108: 9484-9489.

Chuang CY, Lord MS, Melrose J, Rees MD, Knox SM, Freeman C, Iozzo RV, Whitelock JM (2010) Heparan sulfate-dependent signaling of fibroblast growth factor 18 by chondrocyte-derived perlecan. Biochemistry 49: 5524-5532.

Condie BG, Capecchi MR (1993) Mice homozygous for a targeted disruption of Hoxd-3 (Hox-4.1) exhibit anterior transformations of the first and second cervical vertebrae, the atlas and the axis. Development 119: 579-595.

Cortes M, Baria AT, Schwartz NB (2009) Sulfation of chondroitin sulfate proteoglycans is necessary for proper Indian hedgehog signaling in the developing growth plate. Development 136: 1697-1706.

Costell M, Mann K, Yamada Y, Timpl R (1997) Characterization of recombinant perlecan domain I and its substitution by glycosaminoglycan and oligosaccharides. Eur J Biochem 243: 115-121.

Dahia CL, Mahoney EJ, Durrani AA, Wylie C (2009) Intercellular signaling pathways active during intervertebral disc growth, differentiation, and aging. Spine (Phila Pa 1976) 34: 456-462.
Diab M, Wu JJ, Eyre DR (1996) Collagen type IX from human cartilage: a structural profile of intermolecular cross-linking sites. Biochem J 314: 327-332.

Doege KJ, Sasaki M, Kimura T, Yamada Y (1991) Complete coding sequence and deduced primary structure of the human cartilage large aggregating proteoglycan, aggrecan. Human-specific repeats, and additional alternatively spliced forms. J Biol Chem 266: 894-902.

Elliott DM, Sarver JJ (2004) Young investigator award winner: validation of the mouse and rat disc as mechanical models of the human lumbar disc. Spine (Phila Pa 1976) 29: 713-722.

Farach-Carson MC, Brown AJ, Lynam M, Safran JB, Carson DD (2008) A novel peptide sequence in perlecan domain IV supports cell adhesion, spreading and FAK activation. Matrix Biol 27: 150-160.

Farach-Carson MC, Warren CR, Harrington DA, Carson DD (2014) Border patrol: Insights into the unique role of perlecan/heparan sulfate proteoglycan 2 at cell and tissue borders. Matrix Biol 34: 64-79.

Flannery CR, Little CB, Caterson B (1998) Molecular cloning and sequence analysis of the aggrecan interglobular domain from porcine, equine, bovine and ovine cartilage: comparison of proteinase-susceptible regions and sites of keratan sulfate substitution. Matrix Biol 16: 507-511.

Foley CJ, Kuliopulos A (2014) Mouse matrix metalloprotease-1a (Mmp1a) gives new insight into MMP function. J Cell Physiol 229: 1875-1880.

Fosang AJ, Rogerson FM, East CJ, Stanton H (2008) ADAMTS-5: the story so far. Eur Cell Mater 15: 11-26.

Fuki I V, Iozzo R V, Williams KJ (2000) Perlecan heparan sulfate proteoglycan. A novel receptor that mediates a distinct pathway for ligand catabolism. J Biol Chem 275: 25742-25750.

Furukawa T, Ito K, Nuka S, Hashimoto J, Takei H, Takahara M, Ogino T, Young MF, Shinomura T (2009) Absence of biglycan accelerates the degenerative process in mouse intervertebral disc. Spine (Phila Pa 1976) 34: E911-E917.

Gajghate S, Hiyama A, Shah M, Sakai D, Anderson DG, Shapiro IM, Risbud MV (2009) Osmolarity and intracellular calcium regulate aquaporin2 expression through TonEBP in nucleus pulposus cells of the intervertebral disc. J Bone Miner Res 24: 992-1001.

Ghiselli G, Eichstetter I, Iozzo RV (2001) A role for the perlecan protein core in the activation of the keratinocyte growth factor receptor. Biochem J 359: 153-163.

Glasson SS, Askew R, Sheppard B, Carito BA, Blanchet T, Ma HL, Flannery CR, Kanki K, Wang E, Peluso D, Yang Z, Majumdar MK, Morris EA (2004) Characterization of and osteoarthritis susceptibility in ADAMTS-4-knockout mice. Arthritis Rheum 50: 2547-2558.

Glasson SS, Askew R, Sheppard B, Carito B, Blanchet T, Ma HL, Flannery CR, Peluso D, Kanki K, Yang Z, Majumdar MK, Morris EA (2005) Deletion of 
active ADAMTS5 prevents cartilage degradation in a murine model of osteoarthritis. Nature 434: 644-648.

Goldring MB (2009) The link between structural damage and pain in a genetic model of osteoarthritis and intervertebral disc degeneration: a joint misadventure. Arthritis Rheum 60: 2550-2552.

Gorth DJ, Ottone OK, Shapiro IM, Risbud MV (2020) Differential effect of long-term systemic exposure of TNF $\alpha$ on health of the annulus fibrosus and nucleus pulposus of the intervertebral disc. J Bone Miner Res 35: 725-737.

Gorth DJ, Shapiro IM, Risbud MV (2018) Transgenic mice overexpressing human TNF- $\alpha$ experience early onset spontaneous intervertebral disc herniation in the absence of overt degeneration. Cell Death Dis 10: 7. DOI: 10.1038/s41419-018-1246-x.

Gorth DJ, Shapiro IM, Risbud MV (2019) A new understanding of the role of IL-1 in age-related intervertebral disc degeneration in a murine model. J Bone Miner Res 34: 1531-1542.

Gruber HE, Bornstein P, Helene EH, Ingram JA, Zinchenko N, James HJ, Hanley EN (2008) Disruption of the thrombospondin-2 gene alters the lamellar morphology but does not permit vascularization of the adult mouse lumbar disc. Arthritis Res Ther 10: R96. DOI: 10.1186/ar2483.

Gruber HE, Sage EH, Norton HJ, Funk S, Ingram J, Hanley EN (2005) Targeted deletion of the SPARC gene accelerates disc degeneration in the aging mouse. J Histochem Cytochem 53: 1131-1138.

Hayes AJ, Melrose J (2021) 3D distribution of perlecan within intervertebral disc chondrons suggests novel regulatory roles for this multifunctional modular heparan sulphate proteoglycan. Eur Cell Mater in press.

Henry SP, Liang S, Akdemir KC, De Crombrugghe B (2012) The postnatal role of Sox9 in cartilage. J Bone Miner Res 27: 2511-2525.

Holguin N, Aguilar R, Harland RA, Bomar BA, Silva MJ (2014) The aging mouse partially models the aging human spine: Lumbar and coccygeal disc height, composition, mechanical properties, and Wnt signaling in young and old mice. J Appl Physiol 116: 1551-1560.

Hollander WF, Strong LC (1951) Pintail, a dominant mutation: linked with brown in the house mouse. J Hered 42: 179-182.

Holmbeck K, Bianco P, Caterina J, Yamada S, Kromer M, Kuznetsov SA, Mankani M, Gehron Robey P, Poole AR, Pidoux I, Ward JM, BirkedalHansen H (1999) MT1-MMP-deficient mice develop dwarfism, osteopenia, arthritis, and connective tissue disease due to inadequate collagen turnover. Cell 99: 81-92.

Huang X, Zhang W, Shao Z (2018) Association between GDF5 rs143383 genetic polymorphism and musculoskeletal degenerative diseases susceptibility: a meta-analysis. BMC Med Genet 19: 169. DOI: 10.1186/s12881-018-0685-7.

Hwang PY, Jing L, Chen J, Lim FL, Tang R, Choi $\mathrm{H}$, Cheung KM, Risbud MV, Gersbach CA, Guilak
F, Leung VY, Setton LA (2016) N-cadherin is key to expression of the nucleus pulposus cell phenotype under selective substrate culture conditions. Sci Rep 6: 28038. DOI: 10.1038/srep28038.

Inada M, Wang Y, Byrne MH, Rahman MU, Miyaura C, López-Otín C, Krane SM (2004) Critical roles for collagenase-3 (Mmp13) in development of growth plate cartilage and in endochondral ossification. Proc Natl Acad Sci U S A 101: 1719217197.

Johnson ZI, Shapiro IM, Risbud MV (2014) Extracellular osmolarity regulates matrix homeostasis in the intervertebral disc and articular cartilage: evolving role of TonEBP. Matrix Biol 40: 10-16.

Johnson ZI, Shapiro IM, Risbud MV (2016) RNA sequencing reveals a role of TonEBP transcription factor in regulation of pro-inflammatory genes in response to hyperosmolarity in healthy nucleus pulposus cells a homeostatic response? J Biol Chem 291: 26686-26697.

Kallunki P, Tryggvason K (1992) Human basement membrane heparan sulfate proteoglycan core protein: A 467-kD protein containing multiple domains resembling elements of the low density lipoprotein receptor, laminin, neural cell adhesion molecules, and epidermal growth factor. J Cell Biol 116: 559-571.

Kato H, Duarte S, Liu D, Busuttil RW, Coito AJ (2015) Matrix metalloproteinase-2 (MMP-2) gene deletion enhances MMP-9 activity, impairs PARP-1 degradation, and exacerbates hepatic ischemia and reperfusion injury in mice. PLoS One 10: e0137642. DOI: 10.1371/journal.pone.0137642.

Knox S, Fosang AJ, Last K, Melrose J, Whitelock J (2005) Perlecan from human epithelial cells is a hybrid heparan/chondroitin/ keratan sulfate proteoglycan. FEBS Lett 579: 5019-5023.

Knox SM, Whitelock JM (2006) Perlecan: how does one molecule do so many things? Cell Mol Life Sci 63: 2435-2445.

Knox S, Melrose J, Whitelock J (2001) Electrophoretic, biosensor, and bioactivity analyses of perlecans of different cellular origins. Proteomics 1: 1534-1541.

Kondo N, Yuasa T, Shimono K, Tung W, Okabe T, Yasuhara R, Pacifici M, Zhang Y, Iwamoto M, Enomoto-Iwamoto M (2011) Intervertebral disc development is regulated by wnt $/ \beta$-catenin signaling. Spine (Phila Pa 1976) 36: E513-E518.

Kovalszky I, Hjerpe A, Dobra K (2014) Nuclear translocation of heparan sulfate proteoglycans and their functional significance. Biochim Biophys Acta 1840: 2491-2497.

Lamb AN, Rosenfeld JA, Neill NJ, Talkowski ME, Blumenthal I, Girirajan S, Keelean-Fuller D, Fan Z, Pouncey J, Stevens C, Mackay-Loder L, Terespolsky D, Bader PI, Rosenbaum K, Vallee SE, Moeschler JB, Ladda R, Sell S, Martin J, Ryan S, Jones MC, Moran R, Shealy A, Madan-Khetarpal S, Mcconnell J, Surti U, Delahaye A, Heron-Longe B, Pipiras E, Benzacken B, Passemard S, Verloes A, Isidor B, Le Caignec C, Glew GM, Opheim KE, Descartes M, 
Eichler EE, Morton CC, Gusella JF, Schultz RA, Ballif BC, Shaffer LG (2012) Haploinsufficiency of SOX5 at 12 p12.1 is associated with developmental delays with prominent language delay, behavior problems, and mild dysmorphic features. Hum Mutat 33: 728-740.

Lark MW, Gordy JT, Weidner JR, Ayala J, Kimura JH, Williams HR, Mumford RA, Flannery CR, Carlson SS, Iwata M, Sandy JD (1995) Cell-mediated catabolism of aggrecan: evidence that cleavage at the "aggrecanase" site (Glu373-Ala374) is a primary event in proteolysis of the interglobular domain. J Biol Chem 270: 2550-2556.

Li B, Zheng XF, Ni BB, Yang YH, Jiang SD, Lu H, Jiang LS (2013) Reduced expression of insulinlike growth factor 1 receptor leads to accelerated intervertebral disc degeneration in mice. Int J Immunopathol Pharmacol 26: 337-347.

Li CG, Liang QQ, Zhou Q, Menga E, Cui XJ, Shu B, Zhou CJ, Shi Q, Wang YJ (2009) A continuous observation of the degenerative process in the intervertebral disc of Smad3 gene knock-out mice. Spine (Phila Pa 1976) 34: 1363-1369.

Li X, Leo BM, Beck G, Balian G, Anderson DG (2004) Collagen and proteoglycan abnormalities in the GDF-5-deficient mice and molecular changes when treating disk cells with recombinant growth factor. Spine (Phila Pa 1976) 29: 2229-2234.

Lin D, Alberton P, Delgado Caceres M, Prein C, Clausen-Schaumann H, Dong J, Aszodi A, Shukunami C, Iatridis JC, Docheva D (2020) Loss of tenomodulin expression is a risk factor for agerelated intervertebral disc degeneration. Aging Cell 19: e13091. DOI: 10.1111/acel.13091.

Little CB, Flannery CR, Hughes CE, Mort JS, Roughley PJ, Dent C, Caterson B (1999) Aggrecanase versus matrix metalloproteinases in the catabolism of the interglobular domain of aggrecan in vitro. Biochem J 344: 61-68.

Little CB, Meeker CT, Hembry RM, Sims NA, Lawlor KE, Golub SB, Last K, Fosang AJ (2005) Matrix metalloproteinases are not essential for aggrecan turnover during normal skeletal growth and development. Mol Cell Biol 25: 3388-3399.

Liu C-F, Eronique Lefebvre V (2015) The transcription factors SOX9 and SOX5/SOX6 cooperate genome-wide through super-enhancers to drive chondrogenesis. Nucleic Acids Res 43: 8183-8203.

Madhu V, Boneski PK, Silagi E, Qiu Y, Kurland I, Guntur AR, Shapiro IM, Risbud MV (2020) Hypoxic regulation of mitochondrial metabolism and mitophagy in nucleus pulposus cells is dependent on HIF-1 $\alpha$-BNIP3 axis. J Bone Miner Res 35: 1504-1524.

Maier JA, Lo Y, Harfe BD (2013) Foxa1 and Foxa2 are required for formation of the intervertebral discs. PLoS One 8: 55528. DOI: 10.1371/journal. pone.0055528.

Matsuo I, Kimura-Yoshida C (2014) Extracellular distribution of diffusible growth factors controlled by heparan sulfate proteoglycans during mammalian embryogenesis. Philos Trans R Soc B Biol Sci 369: 20130545. DOI: 10.1098/rstb.2013.0545.
Matta A, Karim MZ, Isenman DE, Erwin WM (2017) Molecular therapy for degenerative disc disease: clues from secretome analysis of the notochordal cell-rich nucleus pulposus. Sci Rep 7: 45623. DOI: $10.1038 /$ srep45623.

Melrose J, Hayes AJ, Whitelock JM, Little CB (2008) Perlecan, the "jack of all trades" proteoglycan of cartilaginous weight-bearing connective tissues. BioEssays 30: 457-469.

Melrose J, Roughley P, Knox S, Smith S, Lord M, Whitelock J (2006) The structure, location, and function of perlecan, a prominent pericellular proteoglycan of fetal, postnatal, and mature hyaline cartilages. J Biol Chem 281: 36905-36914.

Melrose J, Smith S, Ghosh P, Whitelock J (2003) Perlecan, the multidomain heparan sulfate proteoglycan of basement membranes, is also a prominent component of the cartilaginous primordia in the developing human fetal spine. J Histochem Cytochem 51: 1331-1341.

Merceron C, Mangiavini L, Robling A, Wilson TL, Giaccia AJ, Shapiro IM, Schipani E, Risbud MV (2014) Loss of HIF-1 $\alpha$ in the notochord results in cell death and complete disappearance of the nucleus pulposus. PLoS One 9: e110768. DOI: 10.1371/journal. pone.0110768.

Mercurio S, Latinkic B, Itasaki N, Krumlauf R, Smith JC (2004) Connective-tissue growth factor modulates WNT signalling and interacts with the WNT receptor complex. Development 131: 2137-2147.

Millecamps M, Tajerian M, Naso L, Sage EH, Stone LS (2012) Lumbar intervertebral disc degeneration associated with axial and radiating low back pain in ageing SPARC-null mice. Pain 153: 1167-1179.

Mongiat M, Taylor K, Otto J, Aho S, Uitto J, Whitelock JM, Iozzo R V. (2000) The protein core of the proteoglycan perlecan binds specifically to fibroblast growth factor-7. J Biol Chem 275: 7095-7100.

Murdoch AD, Dodge GR, Cohen I, Tuans RS, Iozzo RV (1992) Primary structure of the human heparan sulfate proteoglycan from basement membrane (HSPG2/perlecan). A chimeric molecule with multiple domains homologous to the low density lipoprotein receptor, laminin, neural cell adhesion molecules, and epidermal growth factor. J Biol Chem 267: 8544-8557.

Nakamichi R, Ito Y, Inui M, Onizuka N, Kayama T, Kataoka K, Suzuki H, Mori M, Inagawa M, Ichinose S, Lotz MK, Sakai D, Masuda K, Ozaki T, Asahara H (2016) Mohawk promotes the maintenance and regeneration of the outer annulus fibrosus of intervertebral discs. Nat Commun 7: 12503. DOI: 10.1038/ncomms12503.

Nasto LA, Seo HY, Robinson AR, Tilstra JS, Clauson CL, Sowa GA, Ngo K, Dong Q, Pola E, Lee JY, Niedernhofer LJ, Kang JD, Robbins PD, Vo N V. (2012) ISSLS prize winner: inhibition of NF- $\kappa B$ activity ameliorates age-associated disc degeneration in a mouse model of accelerated aging. Spine (Phila Pa 1976) 37: 1819-1825. 
Ngo K, Pohl P, Wang D, Leme AS, Lee J, Di P, Roughley P, Robbins PD, Niedernhofer LJ, Sowa G, Kang JD, Shapiro SS, Vo N V. (2017) ADAMTS5 deficiency protects mice from chronic tobacco smoking-induced intervertebral disc degeneration. Spine (Phila Pa 1976) 42: 1521-1528.

Niedernhofer LJ, Garinis GA, Raams A, Lalai AS, Robinson AR, Appeldoorn E, Odijk H, Oostendorp R, Ahmad A, Van Leeuwen W, Theil AF, Vermeulen W, Van Der Horst GTJ, Meinecke P, Kleijer WJ, Vijg J, Jaspers NGJ, Hoeijmakers JHJ (2006) A new progeroid syndrome reveals that genotoxic stress suppresses the somatotroph axis. Nature 444: 1038-1043.

Noonan DM, Fulle A, Valente P, Cai S, Horigan E, Sasaki M, Yamada Y, Hassell JR (1991) The complete sequence of perlecan, a basement membrane heparan sulfate proteoglycan, reveals extensive similarity with laminin A chain, low density lipoprotein-receptor, and the neural cell adhesion molecule. J Biol Chem 266: 22939-22947.

Novais EJ, Diekman BO, Shapiro IM, Risbud MV (2019) p16Ink4a deletion in cells of the intervertebral disc affects their matrix homeostasis and senescence associated secretory phenotype without altering onset of senescence. Matrix Biol 82: 54-70.

Novais EJ, Tran VA, Miao J, Slaver K, Sinensky A, Dyment NA, Addya S, Szeri F, Wetering K, Shapiro IM, Risbud MV (2020) Comparison of inbred mouse strains shows diverse phenotypic outcomes of intervertebral disc aging. Aging Cell 19: e13148. DOI: 10.1111/acel.13148.

Ohta R, Tanaka N, Nakanishi K, Kamei N, Nakamae T, Izumi B, Fujioka Y, Ochi M (2012) Heme oxygenase-1 modulates degeneration of the intervertebral disc after puncture in Bach 1 deficient mice. Eur Spine J 21: 1748-1757.

Ortmann C, Pickhinke U, Exner S, Ohlig S, Lawrence R, Jboor H, Dreier R, Grobe K (2015) Sonic hedgehog processing and release are regulated by glypican heparan sulfate proteoglycans. J Cell Sci 128: 2374-2385.

Pandiar D, Thammaiah S (2018) Physaliphorous cells. J Oral Maxillofac Pathol 22: 296-297.

Pattison ST, Melrose J, Ghosh P, Taylor TKF (2001) Regulation of gelatinase-A (MMP-2) production by ovine intervertebral disc nucleus pulposus cells grown in alginate bead culture by transforming growth factor- $\beta 1$ and insulin like growth factor-I. Cell Biol Int 25: 679-689.

Peters H, Wilm B, Sakai N, Imai K, Maas R, Balling R (1999) Pax1 and Pax9 synergistically regulate vertebral column development. Development 126: 5399-5408.

Phillips KLE, Jordan-Mahy N, Nicklin MJH, Le Maitre CL (2013) Interleukin-1 receptor antagonist deficient mice provide insights into pathogenesis of human intervertebral disc degeneration. Ann Rheum Dis 72: $1860-1867$.

Rajesh D, Dahia CL (2018) Role of Sonic Hedgehog signaling pathway in intervertebral disk formation and maintenance. Curr Mol Biol Reports 4: 173-179.
Ramfrez-Solis R, Zheng H, Whiting J, Krumlauf R, Bradley A (1993) Hoxb-4 (Hox-2.6) mutant mice show homeotic transformation of a cervical vertebra and defects in the closure of the sternal rudiments. Cell 73: 279-294.

Robinson SN, Pisarev VM, Chavez JM, Singh RK, Talmadge JE (2003) Use of matrix metalloproteinase (MMP)-9 knockout mice demonstrates that MMP9 activity is not absolutely required for G-CSF or Flt-3 ligand-induced hematopoietic progenitor cell mobilization or engraftment. Stem Cells 21: 417-427.

Roughley PJ, Lamplugh L, Lee ER, Matsumoto K, Yamaguchi Y (2011) The role of hyaluronan produced by Has2 gene expression in development of the spine. Spine (Phila Pa 1976) 36: E914-E920.

Rutges JPHJ, Duit RA, Kummer JA, Bekkers JEJ, Oner FC, Castelein RM, Dhert WJA, Creemers LB (2013) A validated new histological classification for intervertebral disc degeneration. Osteoarthr Cartil 21: 2039-2047.

Sahlman J, Inkinen R, Hirvonen T, Lammi MJ, Lammi PE, Nieminen J, Lapveteläinen T, Prockop DJ, Arita M, Li SW, Hyttinen MM, Helminen HJ, Puustjärvi K (2001) Premature vertebral endplate ossification and mild disc degeneration in mice after inactivation of one allele belonging to the Col2a1 gene for type II collagen. Spine (Phila Pa 1976) 26: 2558-2565.

Segarini PR, Nesbitt JE, Li D, Hays LG, Yates JR, Carmichael DF (2001) The low density lipoprotein receptor-related protein $/ \alpha 2$-macroglobulin receptor is a receptor for connective tissue growth factor. J Biol Chem 276: 40659-40667.

Semba K, Araki K, Li Z, Matsumoto KI, Suzuki M, Nakagata N, Takagi K, Takeya M, Yoshinobu K, Araki M, Imai K, Abe K, Yamamura KI (2006) A novel murine gene, Sickle tail, linked to the Danforth's short tail locus, is required for normal development of the intervertebral disc. Genetics 172: 445-456.

Shapiro IM, Vresilovic EJ, Risbud MV (2012) Is the spinal motion segment a diarthrodial polyaxial joint: what a nice nucleus like you doing in a joint like this? Bone 50: 771-776.

Silagi ES, Novais EJ, Bisetto S, Telonis AG, Snuggs J, Le Maitre CL, Qiu Y, Kurland IJ, Shapiro IM, Philp NJ, Risbud MV (2020) Lactate efflux from intervertebral disc cells is required for maintenance of spine health. J Bone Miner Res 35: 550-570.

Silagi ES, Schoepflin ZR, Seifert EL, Merceron C, Schipani E, Shapiro IM, Risbud MV (2018a) Bicarbonate recycling by HIF-1-dependent carbonic anhydrase isoforms 9 and 12 is critical in maintaining intracellular $\mathrm{pH}$ and viability of nucleus pulposus cells. J Bone Miner Res 33: 338-355.

Silagi ES, Shapiro IM, Risbud MV (2018b) Glycosaminoglycan synthesis in the nucleus pulposus: dysregulation and the pathogenesis of disc degeneration. Matrix Biol 71-72: 368-379.

Sivakamasundari V, Kraus P, Sun W, Hu X, Lim SL, Prabhakar S, Lufkin T (2017) A developmental transcriptomic analysis of Pax1 and Pax9 in embryonic 
intervertebral disc development. Biol Open 6: 187199.

Skubutyte R, Markova D, Freeman TA, Anderson DG, Dion AS, Williams CJ, Shapiro IM, Risbud MV (2010) Hypoxia-inducible factor regulation of ANK expression in nucleus pulposus cells: possible implications in controlling dystrophic mineralization in the intervertebral disc. Arthritis Rheum 62: 27072715.

Smit TH (2002) The use of a quadruped as an in vivo model for the study of the spine-biomechanical considerations. Eur Spine J 11: 137-144.

Smits P, Lefebvre V (2003) Sox5 and Sox6 are required for notochord extracellular matrix sheath formation, notochord cell survival and development of the nucleus pulposus of intervertebral discs. Development 130: 1135-11468.

Sohn P, Cox M, Chen D, Serra R (2010) Molecular profiling of the developing mouse axial skeleton: a role for Tgfbr2 in the development of the intervertebral disc. BMC Dev Biol 10: 29. DOI: 10.1186/1471-213X10-29.

Stanton H, Rogerson FM, East CJ, Golub SB, Lawlor KE, Meeker CT, Little CB, Last K, Farmer PJ, Campbell IK, Fourie AM, Fosang AJ (2005) ADAMTS5 is the major aggrecanase in mouse cartilage in vivo and in vitro. Nature 434: 648-652.

Stevens JW, Oike Y, Handley C, Hascall VC, Hampton A, Caterson B (1984) Characteristics of the core protein of the aggregating proteoglycan from the Swarm rat chondrosarcoma. J Cell Biochem 26: 247-259.

Stewart MC, Fosang AJ, Bai Y, Osborn B, Plaas A, Sandy JD (2006) ADAMTS5-mediated aggrecanolysis in murine epiphyseal chondrocyte cultures. Osteoarthr Cartil 14: 392-402.

Stickens D, Behonick DJ, Ortega N, Heyer B, Hartenstein B, Yu Y, Fosang AJ, Schorpp-Kistner M, Angel P, Werb Z (2004) Altered endochondral bone development in matrix metalloproteinase 13-deficient mice. Development 131: 5883-5895.

Stott D, Kispert A, Herrmann BG (1993) Rescue of the tail defect of Brachyury mice. Genes Dev 7: 197-203.

Sugimoto Y, Takimoto A, Akiyama H, Kist R, Scherer G, Nakamura T, Hiraki Y, Shukunami C (2012) Scx+/Scx9+ progenitors contribute to the establishment of the junction between cartilage and tendon/ligament. Development 140: 2280-2288.

Tapanadechopone P, Hassell JR, Rigatti B, Couchman JR (1999) Localization of glycosaminoglycan substitution sites on domain V of mouse perlecan. Biochem Biophys Res Commun 265: 680-690.

Teeple E, Aslani K, Shalvoy MR, Medrano JE, Zhang L, Machan JT, Fleming BC, Jay GD (2015) Lubricin deficiency in the murine lumbar intervertebral disc results in elevated torsional apparent modulus. J Biomech 48: 2210-2213.

Tessier S, Risbud MV (2020) Understanding embryonic development for cell-based therapies of intervertebral disc degeneration: toward an effort to treat disc degeneration subphenotypes. Dev Dyn. DOI: $10.1002 / d v d y .217$.

Tessier S, Doolittle AC, Sao K, Rotty JD, Bear JE, Ulici V, Loeser RF, Shapiro IM, Diekman BO, Risbud MV (2020a) Arp2/3 inactivation causes intervertebral disc and cartilage degeneration with dysregulated TonEBP-mediated osmoadaptation. JCI Insight 5: e131382. DOI: 10.1172/jci.insight.131382.

Tessier S, Madhu V, Johnson ZI, Shapiro IM, Risbud MV (2019) NFAT5/TonEBP controls early acquisition of notochord phenotypic markers, collagen composition, and sonic hedgehog signaling during mouse intervertebral disc embryogenesis. Dev Biol 455: 369-381.

Tessier S, Tran VA, Ottone OK, Novais EJ, Doolittle A, DiMuzio MJ, Shapiro IM, Risbud MV (2020b) TonEBP-deficiency accelerates intervertebral disc degeneration underscored by matrix remodeling, cytoskeletal rearrangements, and changes in proinflammatory gene expression. Matrix Biol 87: 94-111.

Theiler K (1959) Anatomy and development of the "truncate" (boneless) mutation in the mouse. Am J Anat 104: 319-343.

Torre OM, Das R, Berenblum RE, Huang AH, Iatridis JC (2018) Neonatal mouse intervertebral discs heal with restored function following herniation injury. FASEB J 32: 4753-4762.

Torre OM, Mroz V, Benitez ARM, Huang AH, Iatridis JC (2019) Neonatal annulus fibrosus regeneration occurs via recruitment and proliferation of Scleraxis-lineage cells. NPJ Regen Med 4: 23. DOI: 10.1038/s41536-019-0085-4.

Tran CM, Fujita N, Huang BL, Ong JR, Lyons KM, Shapiro IM, Risbud MV (2013) Hypoxia-inducible factor (HIF)- $1 \alpha$ and CCN2 form a regulatory circuit in hypoxic nucleus pulposus cells: CCN2 suppresses HIF-1 $\alpha$ level and transcriptional activity. J Biol Chem 288: 12654-12666.

Tran CM, Markova D, Smith HE, Susarla B, Ponnappan RK, Anderson DG, Symes A, Shapiro IM, Risbud MV (2010) Regulation of CCN2/connective tissue growth factor expression in the nucleus pulposus of the intervertebral disc: role of Smad and activator protein 1 signaling. Arthritis Rheum 62: 1983-1992.

Tran CM, Schoepflin ZR, Markova DZ, Kepler CK, Anderson DG, Shapiro IM, Risbud MV (2014) CCN2 suppresses catabolic effects of interleukin-1 $\beta$ through $\alpha 5 \beta 1$ and $\alpha \mathrm{V} \beta 3$ Integrins in nucleus pulposus cells: implications in intervertebral disc degeneration. J Biol Chem 289: 7374-7387.

Trout JJ, Buckwalter JA, Moore KC, Landas SK (1982) Ultrastructure of the human intervertebral disc. I. Changes in notochordal cells with age. Tissue Cell 14: 359-369.

Tsai TT, Danielson KG, Guttapalli A, Oguz E, Albert TJ, Shapiro IM, Risbud MV (2006) TonEBP/ OREBP is a regulator of nucleus pulposus cell function and survival in the intervertebral disc. J Biol Chem 281: 25416-25424. 
Tsingas M, Ottone OK, Haseeb A, Barve RA, Shapiro IM, Lefebvre V, Risbud MV (2020) Sox9 deletion causes severe intervertebral disc degeneration characterized by apoptosis, matrix remodeling, and compartment-specific transcriptomic changes. Matrix Biol 94: 110-133.

Ulici V, Kelley KL, Longobardi L, McNulty MA, Livingston EW, Bateman TA, Séguin CA, Louer CR, Loeser RF (2019) Impaired annulus fibrosus development and vertebral fusion cause severe scoliosis in mice with deficiency of c-Jun NH2terminal kinases 1 and 2. Am J Pathol 189: 868-885.

Van Hove I, Lefevere E, de Groef L, Sergeys J, Salinas-Navarro M, Libert C, Vandenbroucke R, Moons L (2016) MMP-3 deficiency alleviates endotoxin-induced acute inflammation in the posterior eye segment. Int J Mol Sci 17: 1825. DOI: 10.3390/ijms17111825.

Venn G, Mason RM (1985) Absence of keratan sulphate from skeletal tissues of mouse and rat. Biochem J 228: 443-450.

Veras MA, Tenn NA, Kuljanin M, Lajoie GA, Hammond JR, Dixon SJ, Séguin CA (2019) Loss of ENT1 increases cell proliferation in the annulus fibrosus of the intervertebral disc. J Cell Physiol 234: 13705-13719.

Vo N, Seo HY, Robinson A, Sowa G, Bentley D, Taylor L, Studer R, Usas A, Huard J, Alber S, Watkins SC, Lee J, Coehlo P, Wang D, Loppini M, Robbins PD, Niedernhofer LJ, Kang J (2010) Accelerated aging of intervertebral discs in a mouse model of progeria. J Orthop Res 28: 1600-1607.

Walcz E, Deák F, Erhardt P, Coulter SN, Fülöp C, Horvath P, Doege KJ, Glant TT (1994) Complete coding sequence, deduced primary structure, chromosomal localization, and structural analysis of murine aggrecan. Genomics 22: 364-371.

Wang JC (2002) Cellular roles of DNA topoisomerases: a molecular perspective. Nat Rev Mol Cell Biol 3: 430-440.

Wang M, Tang D, Shu B, Wang B, Jin H, Hao S, Dresser KA, Shen J, Im HJ, Sampson ER, Rubery PT, Zuscik MJ, Schwarz EM, O'Keefe RJ, Wang Y, Chen $\mathrm{D}$ (2012) Conditional activation of $\beta$-catenin signaling in mice leads to severe defects in intervertebral disc tissue. Arthritis Rheum 64: 2611-2623.

Wang W, Nyman JS, Ono K, Stevenson DA, Yang X, Elefteriou F (2011) Mice lacking Nf1 in osteochondroprogenitor cells display skeletal dysplasia similar to patients with neurofibromatosis type I. Hum Mol Genet 20: 3910-3924.

Warraich S, Bone DBJ, Quinonez D, Ii H, Choi DS, Holdsworth DW, Drangova M, Dixon SJ, Séguin CA, Hammond JR (2013) Loss of equilibrative nucleoside transporter 1 in mice leads to progressive ectopic mineralization of spinal tissues resembling diffuse idiopathic skeletal hyperostosis in humans. J Bone Miner Res 28: 1135-1149.

Watanabe H, Gao L, Sugiyama S, Doege K, Kimata K, Yamada Y (1995) Mouse aggrecan, a large cartilage proteoglycan: protein sequence, gene structure and promoter sequence. Biochem J 308: 433-440.

Wellik DM, Capecchi MR (2003) Hox10 and Hox11 genes are required to globally pattern the mammalian skeleton. Science 301: 363-367.

Wells JEA, Rice TK, Nuttall RK, Edwards DR, Zekki H, Rivest S, Yong VW (2003) An adverse role for matrix metalloproteinase 12 after spinal cord injury in mice. J Neurosci 23: 10107-10115.

Wilson CL, Ouellette AJ, Satchell DP, Ayabe T, López-Boado YS, Stratman JL, Hultgren SJ, Matrisian LM, Parks WC (1999) Regulation of intestinal $\alpha$-defensin activation by the metalloproteinase matrilysin in innate host defense. Science 286: 113117.

Winkler T, Mahoney EJ, Sinner D, Wylie CC, Dahia CL (2014) Wnt signaling activates Shh signaling in early postnatal intervertebral discs, and re-activates Shh signaling in old discs in the mouse. PLoS One 9: e98444. DOI: 10.1371/journal.pone.0098444.

Wu Q, Wang J, Skubutyte R, Kepler CK, Huang Z, Anderson DG, Shapiro IM, Risbud MV (2012) Smad3 controls $\beta$-1,3-glucuronosyltransferase 1 expression in rat nucleus pulposus cells: implications of dysregulated expression in disc disease. Arthritis Rheum 64: 3324-3333.

Wu WJ, Zhang XK, Zheng XF, Yang YH, Jiang SD, Jiang LS (2013) SHH-dependent knockout of HIF-1 alpha accelerates the degenerative process in mouse intervertebral disc. Int J Immunopathol Pharmacol 26: 601-609.

Wunderle VM, Critcher R, Hastie N, Goodfellow PN, Schedl A (1998) Deletion of long-range regulatory elements upstream of SOX9 causes campomelic dysplasia. Proc Natl Acad Sci U S A 95: 10649-10654.

Yang C, Chen Y, Li Z, Cao H, Chen K, Lai P, Yan B, Huang B, Tang J, Fan S, Cai D, Jin D, Bai X, Zhou R (2017) Chondrocyte-specific knockout of TSC-1 leads to congenital spinal deformity in mice. Biomed Res Int 2017: 8215805. DOI: 10.1155/2017/8215805.

Zeng Y, Danielson KG, Albert TJ, Shapiro IM, Risbud MV (2007) HIF-1 $\alpha$ is a regulator of galectin-3 expression in the intervertebral disc. J Bone Miner Res 22: $1851-1861$.

Zhang C, Smith MP, Zhou GK, Lai A, Hoy RC, Mroz V, Torre OM, Laudier DM, Bradley EW, Westendorf JJ, Iatridis JC, Illien-Jünger S (2019) Phlpp1 is associated with human intervertebral disc degeneration and its deficiency promotes healing after needle puncture injury in mice. Cell Death Dis 10: 754. DOI: 10.1038/s41419-019-1985-3.

Zhang Y, Xiong C, Kudelko M, Li Y, Wang C, Wong YL, Tam V, Rai MF, Cheverud J, Lawson HA, Sandell L, Chan WCW, Cheah KSE, Sham PC, Chan D (2018) Early onset of disc degeneration in SM/J mice is associated with changes in ion transport systems and fibrotic events. Matrix Biol 70: 123-139.

Zieba J, Forlenza KN, Khatra JS, Sarukhanov A, Duran I, Rigueur D, Lyons KM, Cohn DH, Merrill AE, Krakow D (2016) TGF $\beta$ and BMP dependent 
cell fate changes due to loss of filamin B produces disc degeneration and progressive vertebral fusions. PLoS Genet 12: e1005936. DOI: 10.1371/journal. pgen.1005936.

\section{Discussion with Reviewer}

Reviewer 1: Which mouse model, or which combination of the described mouse models, would you recommend for studying spontaneous disc degeneration?

Authors: Spontaneity eludes to a disease process that is not initiated by intentionally made genetic or physical (i.e. AF puncture, tail looping) manipulations. Therefore, the selection of a mouse model that displays spontaneous disc degeneration must be limited to the inbred strains. Furthermore, the acknowledgment that disc degeneration encompasses a diversity of degenerative phenotypes precludes the use of a single model. With that held into consideration, the SM/J and LG/J inbred strains are especially useful, as they have been extensively characterised and show similar degeneration characteristics to that of human disease. $\mathrm{SM} / \mathrm{J}$ mice show degeneration at a relatively early age (Choi et al., 2018b), whereas LG/J mice evidence disc calcification with ageing (Novais et al., 2020). In the case of SM/J mice, the early onset aspect facilitates experimental investigations when time constraints are imposed and helps to lessen the costly housing of mice for extended periods of time, as is done in aging studies.

Editor's note: The Scientific Editor responsible for this paper was Mauro Alini. 